\title{
Impact of Maternal and Child Health Interventions On Under-Five Mortality in Ghana: A Quasi-Experimental Study Design With Coarsened Exact Matching
}

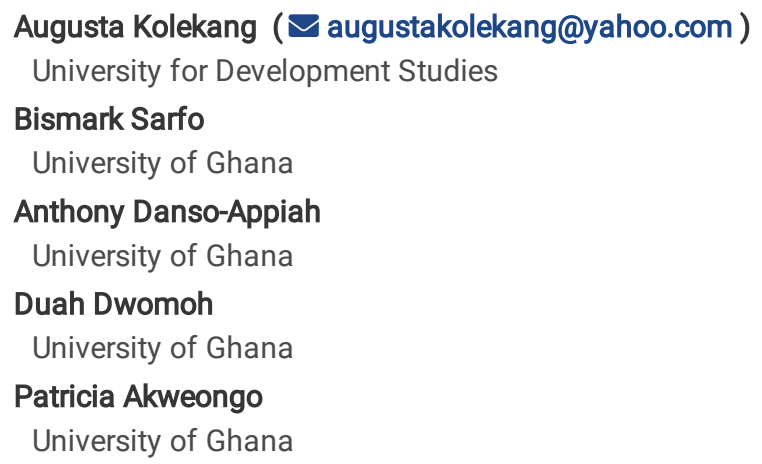




\section{Abstract}

\section{Background}

Despite a $53 \%$ decline in under-five mortality (U5M) worldwide during the period of the Millennium Development Goals (MDGs), U5M remains a challenge. Under-five mortality decline in Ghana is slow and not parallel with the level of coverage of child health interventions. This study sought to assess the effectiveness of these interventions on U5M in Ghana.

\section{Methods}

A quasi-experimental study was conducted using secondary data of the 2008 and 2014 Ghana Demographic and Health Surveys. Coarsened Exact Matching and logistic regression were done.

\section{Results}

There were 6,098 children under-five years old and 93 (1.46\%) died. Among the children who died, 47 (47\%) were less than one month old. Coverage of antenatal care visits was the highest coverage level with 5,045 (84.0\%) while water connection in the home was the lowest coverage level of 469 (8.1\%). Less than 1.5\% (58) of children received all eight (8) interventions and none of those who received all the eight interventions died. After controlling for potential confounders, clean postnatal care for babies within 2 days after delivery caused a $64 \%$ reduction in the average odds of death $(\mathrm{aOR}=0.36,95 \% \mathrm{Cl}: 0.15,0.90)$ while early initiation of breastfeeding caused a $61 \%$ reduction in the average odds of death $(\mathrm{aOR}=0.39,95 \% \mathrm{Cl}: 0.22-0.71)$. In the midst of the various interventions, some socio-demographic factors placed children at higher odds of death. Children with less than two years preceding birth interval, being a neonate, multiple birth, or from a polygamous home put children at a higher odds of under-five mortality.

\section{Conclusion}

Two out of eight interventions caused reduction in the average odds of death. A further decline in under-five mortality in Ghana will require increase in the coverage levels of these two high impact interventions. Additionally, attention should be paid to children at higher risk of dying including neonates, multiple births, children from polygamous homes and those with preceding birth interval less than two years.

\section{Research In Context}

\section{What is already known?}

- Increasing coverage of child health interventions has been advocated in order to achieve rapid decline in mortality.

- However, the effectiveness of these interventions can be sub-optimal, and some interventions have been associated with increased risk of death of children.

\section{What are the new findings?}

- This study assessed interventions effective at reducing U5M in Ghana.

- Early initiation of breastfeeding and clean postnatal care caused reduction in the average odds of death.

- In the midst of the various interventions, children with preceding birth interval less than two years, being a neonate, from a multiple birth, or a polygamous home, put children at a higher risk of under-five mortality.

\section{What do the new findings imply?}

- Few (2/8) interventions showed effectiveness on mortality reduction. This suggests that the coverage and content of the current package of interventions targeted at reducing U5M will likely not achieve rapid decline in mortality.

- To achieve further decline in mortality, coverage of early initiation of breastfeeding and clean postnatal care should be increased since their coverage levels are low.

- Attention should be paid to children at higher risk of dying including neonates, multiple births, children from polygamous homes and those with preceding birth interval less than two years.

\section{Introduction}

Under-five mortality (U5M) remains a major public health problem despite a 53\% decline globally between 1990 and 2015(1). Decline of U5M in Ghana is considered slow(2-4). Thus, it could not achieve the Millennium Development Goal (MDG) 4 target $(4,5)$ despite several efforts at 
achieving it. According to Schieber, Cashin (2), Ghana's under-five mortality rate is not commensurate with its high health care spending compared to other countries at the global level(2).

Variations in socio-demographic factors including household, maternal and child factors(6, 7), prevalence of diseases and risk factors as well as impact of interventions(8-10) underpin the variations in mortality decline. To this end, maternal, neonatal, child health and nutrition interventions have been advocated to reduce U5M. Child health interventions in Ghana include antenatal care visit, postnatal care visit, early initiation of breastfeeding, health facility and skilled delivery and household ownership of mosquito net. Several strategies including the Community-based Health Planning Services (CHPS), and the National Health Insurance Scheme (NHIS) have been implemented to increase access to and coverage of child health interventions and to improve survival(3). This has resulted in increased coverage levels of most vaccines to $80 \%$ in $2014(11)$. However, coverage levels of some other interventions, including clean postnatal care, improved sanitation and water connection in the home were below $30 \%$ in Ghana in 2014(3).

While low coverage of interventions lead to low impact(12-14), the impact of interventions can be low even when coverage is high, if the quality of the interventions are poor or there are adverse events associated with the interventions. Poorer child survival has been documented with health facility and skilled delivery compared to home deliveries(15), iron intake(16), diphtheria, pertussis and tetanus (DPT) vaccine(17, 18), and malaria vaccine $(19,20)$. To achieve rapid mortality decline and possibly achieve the Sustainable Development Goals (SDG) 3.2 , information on interventions with the potential to rapidly reduce mortality is required. This study, therefore, sought to assess the effectiveness of the child health interventions implemented in Ghana. The null hypothesis was that no intervention caused decrease in U5M in Ghana during the period of the evaluation.

\section{Methods}

\section{Study design}

This was a quasi-experimental study design used to assess the effectiveness of eight (8) interventions. The Mosley and Chen framework for studying child survival in developing countries was adapted for this study(21). The interventions were antenatal care visits, neonatal tetanus toxoid vaccination, clean postnatal care, hygienic disposal of stool, early initiation of breastfeeding, intermittent preventive treatment of malaria in pregnancy (IPT-p), iron intake, and skilled delivery. These are interventions expected to be implemented before, during or shortly after birth, and that are therefore likely to have preceded (temporal association between exposure and outcome) death for those children who received them(22). In addition, an overall or composite intervention group was created using children who received all of the eight (8) interventions. Definition of interventions can be found in the 2014 Ghana Demographic and Health Survey(11). For each child that received an intervention (treated), a control child who did not receive the intervention (untreated) was matched using coarsened exact matching(23-26).

\section{Study area}

The study area was Ghana, a country in sub-Saharan Africa (SSA). There were 10 political regions and 216 districts in Ghana in 2008 and 2014. At the last census in 2010, the total population of Ghana was about 25 million(27). Agriculture and services sectors contributed the most to the economy during the period of the evaluation(28). On general health, burden of illness or injury was $14 \%$ in 2014 with individuals 50 years old and above (22.4\%) and children 0-5 years (20.3\%) reporting the highest burden(28).

Regarding the eating habits of Ghanaians, results from the literature are inconsistent. While Buxton (29) recorded that $63 \%$ of Junior High Students in Ghana reported skipping breakfast on school going days, Intiful and Lartey (30) recorded that $86 \%$ of students aged 6-19 years old in the Eastern Region of Ghana had breakfast on the day they were interviewed. Forty-five percent (45\%) adolescents reported eating two homecooked meals a day and 34\% preferred a soft drink during the day (29). Rural dwellers consumed more starchy foods while urban dwellers consumed more animal-based foods(31). Skipping of breakfast, low consumption of fruits and vegetables and high consumption of energy dense foods have also been reported among university students in Ghana(32).

\section{Study participants}

The study population was children under-five years old in the GDHS data sets born between 2003 and 2014 . The analyses were restricted to usual household members and last births. The last birth restriction was done because interventions including antenatal care visits, iron intake and clean postnatal care, were measured for only the last births. It would also reduce the effect of recall bias on the study results. Only usual household members were also used because some interventions were not measured for none usual household members.

\section{Data and source of data}

Secondary data from the 2008 and 2014 Ghana Demographic and Health Surveys (GDHS) were used. The data were collected by the Ghana Statistical Service. The GDHS are complex household surveys, and the data were collected using a cross-sectional descriptive study design. Individuals were selected using a multistage cluster sampling technique(3). The data are nationally representative and response rates were over 
$90 \%$ for both surveys used in this analysis(3). Data sets of the 2008 and 2014 surveys were pooled for the analysis. The years 2008 and 2014 were chosen because they are the data sets closest to the transition from the MDGs to the SDGs. Information from the study will therefore provide understanding of the interventions that contributed to mortality reduction towards the end of the MDGs, and thus should be focused on during the SDGs period in order to achieve rapid mortality reduction.

The Household Recode (HR) and Children Recode (KR) files were used for this analysis. The KR file was the main data set and it contained information of children under-five years old at the start of the data collection whose mothers where interviewed(3). The 2008 GDHS data set had 2,882 observations and 1,010 variables while the 2014 had 5,884 observations and 1,159 variables (figure 1). The Stata versions of the datasets were downloaded from the DHS Program's website (https://dhsprogram.com). The HR datasets were merged with the KR data sets so that household insecticide treated nets/indoor residual spraying (ITN/IRS) information from the HR data set could be added to the KR data set. Household insecticide treated nets/indoor residual spraying is an intervention and a potential confounder and needed to be adjusted for in the analysis. The data sets of 2008 and 2014 were combined to obtain the final data set for the analysis.

Forty-eight percent (48\%) of observations had at least one missing value for the covariates to be adjusted for and therefore multiple imputation was done before the regression analysis were done. Imputation was done to preserve sample size and representativeness of the data. Variables with missing data were birth interval (16 observations), number of cowives (832 observations), mode of delivery of child (2 observations), child's weight (19 observations), employment status of mother (13 observations), NHIS status (1 observation), maternal BMI (2,601), anaemia (204), height $(2,008)$ and child given other milk within three days after birth (58). Twenty (20) imputations were done using chain imputation and logistic regression. Imputation data format was marginal long and seed set was 200 . Variables used in the multiple imputation were all variables without missing data that were used in the analysis. The design feature, weighting, was factored into the multiple imputation model. The stata syntax of the multiple imputation is presented in additional file 1.

\section{Study variables}

The variables used in this analysis were socio-economic and demographic variables, and interventions. Socio-economic factors were maternal and household factors including maternal education, marital status, religion, ethnicity, household wealth, household size, number of children under-five years in a household, region, and place of residence. Demographic factors comprised child and maternal factors including maternal age, child's age and birth weight, birth interval, birth order and multiple birth. Interventions were antenatal visit, IPT-p, iron intake, tetanus toxoid vaccine, skilled delivery, clean postnatal care, early initiation of breastfeeding, hygienic disposal of stool, water connection in the home, improved water source, improved sanitation, ITN/IRS, antenatal care visits, and NHIS status. The year of the survey was also included. Definition of variables were based on the 2014 GDHS report (3).

\section{Pre-processing of data}

Coarsened Exact Matching (23) was used to pre-process (match) the data to ensure balance in pre-treatment variables (covariates) between the treated and untreated groups. Covariate balance was assessed using linear 1 (L1) statistic. L1=0 means perfect covariate balance between treated and untreated groups while $L 1=1$ means complete incompatible treatment and comparison groups with respect to the covariates. The closer the values of L1 to zero, the better the covariate balance(23). Information on the sample size and covariate balance before and after matching are presented in table 1.

CEM puts observations into groups based on factors that influenced decision to received treatment. The groups were chosen by the researcher to reflect clinically important categories and to be consistent with that in the GDHS reports. Observations in similar groups were matched and treated and untreated individuals who did not have matches were deleted from the data set and the data analyzed as unmatched data. The covariates used in the matching process were variables that predicted intervention use from the literature review and were also associated with the intervention from chi-square test done in this data analysis (Table 1).

\section{Analysis}

Descriptive statistics were done and presented as numbers (percentage) by survival status (died or lived) and chi-squared test was used to assess the differences. Logistic regression was also fitted to assess factors associated with U5M after the multiple imputation. The design features (stratification, clustering and weighting and selection of primary sampling units) of the GDHS were factored into all the analysis. Also, the differences in women's population between the two time periods was also accounted for in the analysis. De-normalise weights were used to account for the differences in the population of women in reproduction age in the population at the time of each survey. The de-normalised weight was calculated as

$=\underline{\Psi \times} \phi 15-49 / \phi^{S} 15-49(33)$. Where $\psi$ is the DHS sampling weight for women. $\phi 15-49$ is the population of women in the country at the time of each survey, while $\phi^{S} 15-49$ is the total number of women 15-49 years interviewed during the data collection for each of the survey as reported in the GDHS reports $(11,34)$. 
Potential confounders adjusted for were those related to mortality and/or exposure from the conceptual framework and are not intermediates in the causal pathway of the exposure and outcome $(35,36)$. Robust estimates of odds ratios (ORs) with $95 \%$ confidence interval were reported.

For the analysis of causal effect, under the null hypothesis that no intervention had a causal effect on U5M, a logistic regression was fitted using the pre-processed CEM data. Each intervention (antenatal care visit, IPT-p, iron intake, tetanus toxoid vaccine, skilled delivery, clean postnatal care, early initiation of breastfeeding, and hygienic disposal of stool) was the exposure, accounting for design features, and controlling for potential confounders. Potential confounders adjusted for were those identified from the conceptual framework. Average treatment effects were reported as OR with $95 \% \mathrm{Cl}$ and at a 2-tailed a level of $0.05(37)$. Analyses were performed using STATA version 13 . The CEM syntax and algorithm are included in additional file 1.

\section{Sensitivity analysis}

\section{Complete case analysis without matemal nutrition factors}

When logistic regression was fitted with the completed cases, the total number of observation was 5,224 and early initiation of breastfeeding, child's age, multiple birth, birth interval, number of children under-five years old in the household and polygamy were associated with U5M from the adjusted analysis.

\section{Multiple imputation with maternal nutrition factors}

After multiple imputation, when maternal anaemia and Body Mass Index (BMI) were added, the sample size reduced from 6,098 to 3,165 observations with very wide $95 \%$ confidence intervals and the variable, water connection in the home omitted from the regression model. BMI and anaemia were not statistically significant while household size, child's age, multiple birth, maternal education, household indoor residual spraying and bed net ownership, sex of household head and early initiation of breast feeding were statistically significant. National Health Insurance Scheme status, had borderline significance, $p=0.05$. Confidence interval for multiple births ranged from 9.83 to 417.8 .

\section{Coarsened exact matching with completed cases without maternal nutrition factors}

For the CEM analysis with completed cases, sample size after matching for the regression analysis ranged from 4,914 to 6,043 observations. Only early initiation of breastfeeding had causal effect on U5M reduction from both the crude and adjusted analysis. Clean postnatal care and hygienic disposal of stool were significant from the crude analysis but not from the adjusted analysis.

\section{Results}

\section{Descriptive statistics}

There were 6,098 children under-five years and 93 (1.46\%) died (Table 3). Among children who died, 47 (47\%) were less than one month old. A greater proportion 27 (37\%) of mothers had primary education as their highest level of education. Fifty-six, representing $65.7 \%$ of children were born to mothers below 35 years. Among the interventions, coverage of antenatal care visits was the highest coverage level 5,045 (84.0\%) while water connection in the home was the lowest coverage level $469(8.1 \%)$ (Table 4). Less than 1.5\% (58) of children received all the eight (8) interventions and none of those who received all eight interventions died.

\section{Socio-demographic factors and interventions associated with under-five mortality}

Results of the association of child, maternal and socio-demographic factors with U5M are presented in Table 6. The crude and adjusted ORs and $95 \% \mathrm{Cl}$ for the associations are presented. On child factors, after controlling for potential confounders, compared to children less than 1 month old, odds of death was reduced by $98 \%$ (aOR=0.02, $95 \% \mathrm{Cl}$ : $0.01-0.04)$ among children $1-5$ months. Also, a $98 \%$ reduction of odds of death was reported among those $6-11$ months (aOR=0.02, 95\% Cl: 0.01-0.05) and 99\% among those $12-59$ months (aOR=0.01, 95\%Cl: 0.002-0.01) relative to those less than 1 month old. Children who were multiple births were 7 times more likely to die compared to singleton births (aOR=6.68, $95 \% \mathrm{Cl}$ : 1.56-28.56), while those with preceding birth interval of less than two years twice more likely to die relative to those with longer birth interval $(\mathrm{aOR}=2.25,95 \% \mathrm{Cl}: 1.10-4.60)$. On household factors, children in households with 3 or more children under-five years had their odds of death reduced by $81 \%(\mathrm{aOR}=0.19,95 \% \mathrm{Cl}$ : 0.07-0.51) compared to those in households with one or two children under five years old. Also, children in polygamous homes were 2 times more likely to die compared to children in monogamous homes (aOR=2.16, 95\% Cl: 1.05-4.44). Odds of death was reduced by $46 \%$ among children whose mothers had health insurance coverage $(\mathrm{aOR}=0.54,95 \% \mathrm{Cl}: 0.31-0.96)$.

\section{Interventions with causal effect on under-five mortality}

The crude and adjusted ORs of the causal effect of the interventions are presented in tables 2 and 5 . From the crude analysis, average odds of death was reduced by $68 \%$ among those with early initiation of breastfeeding (OR=0.32, 95\% Cl: $0.19-0.54)$ and $65 \%$ among children under-five years who had clean postnatal care within 2 days $(\mathrm{OR}=0.35,95 \% \mathrm{Cl}: 0.18,0.70)$. After adjusting for potential confounders, early initiation of 
breastfeeding reduced odds of death by $61 \%(\mathrm{aOR}=0.39,95 \% \mathrm{Cl}: 0.22-0.71)$ while clean postnatal care caused a $64 \%$ reduction in the average odds of death (aOR=0.36, 95\% Cl: $0.15,0.90)$ (Tables 2 and 5).

\section{Discussion}

\section{Interventions with causal effect on under-five mortality}

Despite efforts at reducing U5M, mortality decline in Ghana is slow. Although interventions targeted at reducing under-five mortality might show efficacy under experimental conditions, their effectiveness might be suboptimal resulting in their low impact on mortality. This study evaluated the effectiveness of the various child health interventions on U5M in Ghana. The results showed that the various child health interventions impact child mortality differently.

Children who had clean postnatal care had a $64 \%$ reduced average odds of death. Clean postnatal care is defined as neonates receiving a preventive postnatal visit within 48 hours of delivery(3). The assumption is that neonates who receive clean postnatal care will subsequently receive adequate clean postnatal care in the home $(3,38)$.

Sepsis is a major cause of neonatal mortality and cord care influences the incidence of neonatal sepsis. Therefore clean birth and postnatal care practices are recommended for reducing infection and neonatal mortality(39) and thus the recommendation that women after delivery have postnatal care within 48 hours. This will ensure that infections are identified early for timely management. Clean postnatal care can significantly contribute to the elimination of neonatal tetanus which is a major contributor to neonatal mortality(40). From the $2014 \mathrm{Ghana}$ Demographic and Health Survey, mothers received clean postnatal either from skilled attendants or from traditional birth attendants. Skilled health workers include doctors, nurses, midwives, community health nurses or community health officers. Clean postnatal care is one of the interventions with the lowest coverage levels in Ghana. Coverage in 2008 was $6.5 \%$ while that in 2014 was $22.8 \%(11)$. Its low coverage is therefore an avenue to further reduce deaths if its coverage level is increased. Results of the protective effect of clean postnatal care on mortality in this study is similar to that documented(5, 41-43).

Breastfeeding have been shown to reduce the risk of infections and consequently death of children under-five years old(41, 44-47). Early breastfeeding has additional benefits as it promotes warmth and bonding between infants and their mothers. In this study, early initiation of breastfeeding caused a $61 \%$ reduction in the average odds of death. Similar results of the association between early initiation of breastfeeding and under-five mortality have been documented(44-48). According to the GDHS, coverage level of early initiation of breastfeeding was $25.5 \%$ in $1998,46.3 \%$ in $2003,52.3 \%$ in 2008 and $55.6 \%$ (38) in 2014(3). This trend of coverage increase is slow. Considering the 2014 coverage level of the intervention, it has the potential to further reduced mortality if its coverage level is increased. Since this intervention does not require much logistics or expenditure to implement compared to interventions like skilled delivery, it should be prioritized.

\section{Other factors and under-five mortality}

In the midst of interventions, some socio-demographic factors remained associated with U5M. Children in households with three or more children under-five years were $81 \%$ less likely to die compared to those in households with one or two children. Having more children under-five years could mean the mother will have more experience with taking care of children including identifying signs and symptoms of diseases. Having more children under-five years in a household has been associated with early care seeking in Niger(49). Children in households with higher number of members also had reduced odds of neonatal and under-five mortality in Ghana(33).

Health insurance membership offers financial access to healthcare and is association with increased and timely healthcare seeking(50-52). It could therefore increase the use of all the healthcare associated interventions, and therefore, its association with a $46 \%$ reduction in the odds of death of children under-five years in this study. Similar result of the protective effect of NHIS on mortality has been reported(33).

The higher odds of death of younger children and multiple births have been documented(41). In this study, while multiple births were about 7 times more likely to die, compared to neonates, odds of deaths was reduced by about $99 \%$ among children 12 months and older. Addressing the increased odds of death with multiple births and younger children will require improved access to quality skilled delivery. Unfortunately, skilled delivery was not associated with mortality reduction. Younger children, especially neonates, are less developed and more susceptible to infections. However, specialized and advanced care needed at the neonatal period are usually not available especially in poverty ridden communities. Considering the causes of neonatal deaths such as sepsis, diarrhoea, pneumonia and asphyxia, quality skilled delivery, improved nutrition and improved hygiene will play important roles in its reduction(53). But, coverages of hygiene and sanitation interventions are among the interventions with the lowest coverage levels in $\operatorname{Ghana}(3,38)$. Also, coverage of exclusive breastfeeding and complementary feeding are on the decline $(3,38)$.

Additionally, children from mothers in polygamous marriages had twice higher odds of death. This finding is consistent with results reported in other studies $(54,55)$. Rivalry among wives was attributed to the higher odds of death. Limited resources and overcrowding have also been cited as reasons for the positive correlation of polygamy and child mortality(56). 
Lastly, children of birth intervals of less than two years also had twice higher odds of death compared to those of longer intervals. With shorter birth interval, mothers might not have replenished nutrients used up during the previous pregnancy resulting in under-nutrition(57). After delivery, there will be competition for maternal resources including time to care for the children. This can compromise the quality of their care resulting in infections, improper nutrition and poor health. Shorter birth interval will also limit the duration of breastfeeding which can affect the development of the older child. Similar results on the higher risk of death among children with shorter birth intervals have been documented in Ghana(5, 58$)$.

The lack of effect of the other interventions on under-five mortality could be attributed to the context of the implementation of these interventions. The context could include the incidence of the disease(s) each intervention is targeted at, and the quality of the implementation of the interventions. There is evidence of poor quality of skilled delivery contributing to lack of effect of skilled delivery on child mortality(59). Disparities in the association of skilled delivery with neonatal mortality have been documented in different geographic areas. While skilled delivery improved neonatal mortality in Latin America and the Caribbean, it was associated with worse neonatal mortality in Africa(60). The quality and availability of logistics and health personnel for skilled delivery might explain the differences in effectiveness of skilled delivery in different places(60).

Low incidence of disease that the intervention is targeted at could also explain the lack of statistical significance of the association between interventions and under-five mortality(61). With low incidence of disease, the intervention will have fewer deaths to prevent and therefore, low effectiveness. That could be the case for tetanus toxoid vaccine. Improvement in birthing practices could reduce infections due to Clostridium tetani, and therefore, low risk of neonatal tetanus, a resultant reduced risk of death from neonatal tetanus. Currently, Ghana is at the elimination state of neonatal tetanus which means lower risk of neonatal tetanus infection(61).

With multiple interventions which have direct and indirect effect on under-five mortality been implemented in the midst of socio-economic factors that also have effect on under-five mortality, Chowdhury (62) observed that proximate factors have a stronger effect on under-five mortality than more distal factors. Iron intake, antenatal care visits and intermittent preventive treatment of malaria in pregnancy (IPT-p) have relatively indirect effect on U5M and therefore, could account for their lack of statistical significant effect on mortality.

\section{Limitations and strength of study}

On limitations, coarsened exact matching like other matching methods matches on measured potential confounders. However, the confounders adjusted for in this analysis comprised all potential confounders and therefore, the effect of unobserved variables is ignorable. The pooling of the data also increased the power of the study and thus the validity of the results. The matching method that was used reduced model dependence and thus, increases the robustness of the analysis. Lastly, the restriction of the analysis to only the last births reduced the influence of recall bias on the study results. On the strengths of the study, nationally representative data were used which had high response rates (over $90 \%$ ) and therefore, the study findings are generalizable.

\section{Conclusion}

In conclusion, of the eight (8) interventions assessed for effectiveness at reducing under-five mortality, two (2) interventions showed effectiveness on mortality reduction. This therefore suggests that the scope and content of the current package of interventions targeted at reducing $\mathrm{U} 5 \mathrm{M}$, will likely not achieve rapid decline in mortality. At best, the mortality rate will be stagnant. To achieve further decline in mortality, coverage of early initiation of breastfeeding and clean postnatal care should be increased. Early initiation of breastfeeding and clean postnatal care reduce the incidence of sepsis which is a major cause of neonatal deaths. Since the decline in neonatal mortality lags that of other age groups of children under-five years, the Ministry of Health $(\mathrm{MOH})$ and the Ghana Health Service (GHS) should put more emphasis on education of mothers on early initiation of breastfeeding and clean postnatal care at antenatal care and child welfare visits. In the midst of the various interventions, being a neonate, multiple birth or from a polygamous home put children at a higher risk of under-five mortality. Addressing issues affecting the health of children in polygamous homes and multiple births could be beneficial. In contrast, belonging to a home with more number of children under-five years and, a mother with health insurance coverage reduced odds of death. Therefore, measures to improve on the services of the National Health Insurance Scheme, including improving the availability of diagnostic and treatment logistics might contribute to improved child survival.

\section{Abbreviations}

\section{CEM Coarsened Exact Matching}

CHPS Community-based Health Planning Services

DPT Diphtheria, Pertussis and Tetanus

GDHS Ghana Demographic and Health Survey

GHS Ghana Health Service 
HR Household Recode

ITN/IRS Household Insecticide Treated Bed Nets and Indoor Residual Spraying

IPTP Intermittent Preventive Treatment of Malaria in Pregnancy

KR Children Recode

MDGs Millennium Development Goals

$\mathrm{MOH}$ Ministry of Health

NHIS National Health Insurance Scheme

OR Odds Ratio

SDGs Sustainable Development Goals

SSA Sub-Saharan Africa

U5M Under-five Mortality

WHO World Health Organization

\section{Declarations}

\section{Ethics issues and consent to participate}

Publically available data were used. The study did not involve human subjects as secondary data was used.

\section{Consent for publication}

Not applicable

\section{Availability of data and materials}

Data used for this work are available with the corresponding author and also on the website of the DHS Program (https://dhsprogram.com).

\section{Competing interest}

The authors declare that they have no competing interest.

\section{Funding}

This study was funded by the International Fellowships Programme Alumni Awards, United States of America. The funding agent had no role in the conception, design, execution, analysis and interpretation of the study, and the writing of the report.

\section{Authors' contributions}

AK, PA, BS and ADP conceptualised the study. AK and DD conducted the analysis. AK interpreted results and wrote the paper. PA, BS, ADP and DD reviewed the paper. All authors have read and approved the manuscript.

\section{Acknowledgement}

We acknowledge the International Fellowships Programme Alumni Awards for the financial support for this work. The DHS Program granted us permission to use their data for the work and we are grateful to them. Lastly, we are grateful to Dr Ebenezer Owusu Adjah of Novotech, Australia, for reviewing the manuscript.

\section{References}


1. United Nations. The Millennium Development Goals Report 2015. 2015.

2. Schieber G, Cashin C, Saleh K. Health financing in Ghana: World Bank Publications; 2012.

3. Ghana Statistical Service. Ghana Demographic and Health Survey 2014. 2015.

4. Kayode GA, Grobbee DE, Koduah A, Amoakoh-Coleman M, Agyepong IA, Ansah E, et al. Temporal trends in childhood mortality in Ghana: impacts and challenges of health policies and programs. Global health action. 2016;9(1):31907.

5. Kayode GA, Ansah E, Agyepong IA, Amoakoh-Coleman M, Grobbee DE, Klipstein-Grobusch K. Individual and community determinants of neonatal mortality in Ghana: a multilevel analysis. BMC pregnancy and childbirth. 2014;14:165.

6. Akseer N, Kamali M, Bakhache N, Mirza M, Mehta S, Al-Gashm S, et al. Status and drivers of maternal, newborn, child and adolescent health in the Islamic world: a comparative analysis. The Lancet. 2018;391(10129):1493-512.

7. Quansah E, Ohene LA, Norman L, Mireku MO, Karikari TK. Social Factors Influencing Child Health in Ghana. Plos One. 2016;11(1):e0145401-e.

8. Ruducha J, Mann C, Singh NS, Gemebo TD, Tessema NS, Baschieri A, et al. How Ethiopia achieved Millennium Development Goal 4 through multisectoral interventions: a Countdown to 2015 case study. The Lancet Global Health. 2017;5(11):e1142-e51.

9. Jones G, Steketee RW, Black RE, Bhutta ZA, Morris SS, Group BCSS. How many child deaths can we prevent this year? The lancet. 2003;362(9377):65-71.

10. Black RE, Levin C, Walker N, Chou D, Liu L, Temmerman M. Reproductive, maternal, newborn, and child health: key messages from Disease Control Priorities 3rd Edition. The Lancet. 2016;388(10061):2811-24.

11. Ghana Statistical Service (GSS), Ghana Health Service (GHS), ICF I. Ghana Demographic and Health Survey 2014. Rockville, Maryland, USA: GSS, GHS, and ICF; 2015.

12. Ayalneh AA, Fetene DM, Lee TJ. Inequalities in health care utilization for common childhood illnesses in Ethiopia: evidence from the 2011 Ethiopian Demographic and Health Survey. International journal for equity in health. 2017;16(1):67.

13. Tefera W, Tesfaye H, Bekele A, Kayessa E, Waltensperger KZ, Marsh DR. Factors influencing the low utilization of curative child health services in Shebedino District, Sidama Zone, Ethiopia. Ethiopian medical journal. 2014;52(Suppl 3):109-17.

14. Young M, Wolfheim C, Marsh DR, Hammamy D. World Health Organization/United Nations Children's Fund joint statement on integrated community case management: an equity-focused strategy to improve access to essential treatment services for children. The American journal of tropical medicine and hygiene. 2012;87(5_Suppl):6-10.

15. Abir T, Agho KE, Page AN, Milton AH, Dibley MJ. Risk factors for under-5 mortality: evidence from Bangladesh Demographic and Health Survey, 2004-2011. BMJ open. 2015;5(8):e006722.

16. Sazawal S, Black RE, Ramsan M, Chwaya HM, Stoltzfus RJ, Dutta A, et al. Effects of routine prophylactic supplementation with iron and folic acid on admission to hospital and mortality in preschool children in a high malaria transmission setting: community-based, randomised, placebo-controlled trial. Lancet (London, England). 2006;367(9505):133-43.

17. Aaby P, Ravn H, Fisker AB, Rodrigues A, Benn CS. Is diphtheria-tetanus-pertussis (DTP) associated with increased female mortality? A metaanalysis testing the hypotheses of sex-differential non-specific effects of DTP vaccine. Transactions of the Royal Society of Tropical Medicine and Hygiene. 2016;110(10):570-81.

18. Mogensen SW, Andersen A, Rodrigues A, Benn CS, Aaby P. The introduction of diphtheria-tetanus-pertussis and oral polio vaccine among young infants in an urban African community: a natural experiment. EBioMedicine. 2017;17:192-8.

19. Klein SL, Shann F, Moss WJ, Benn CS, Aaby P. RTS, S malaria vaccine and increased mortality in girls. Am Soc Microbiol; 2016.

20. Clemens J, Moorthy V. Implementation of RTS, S/AS01 malaria vaccine-the need for further evidence. Mass Medical Soc; 2016.

21. Mosley WH, Chen LC. An analytical framework for the study of child survival in developing countries. Population and development review. 1984;10:25-45.

22. Rothman KJ, Greenland S. Causation and causal inference in epidemiology. American journal of public health. 2005;95(S1):S144-S50.

23. lacus S, King G, Porro G. CEM: Coarsened exact matching software. 2009.

24. lacus SM, King G, Porro G. Matching for causal inference without balance checking. 2008.

25. lacus SM, King G, Porro G. CEM: software for coarsened exact matching. 2009.

26. lacus SM, King G, Porro G. Causal inference without balance checking: Coarsened exact matching. Political analysis. 2012;20(1):1-24.

27. Ghana Statistical Service. 2010 Population \& Housing Census National Analytical Report. 2013.

28. Ghana Statistical Service. Ghana Living Standards Survey. 2014 July 5, 2019.

29. Buxton CNA. Ghanaian junior high school adolescents dietary practices and food preferences: implications for public health concern. Journal of Nutrition \& Food Sciences. 2014;4(5):1.

30. Intiful F, Lartey A. Breakfast habits among school children in selected communities in the eastern region of Ghana. Ghana medical journal. 2014;48(2):71-7. 
31. Galbete C, Nicolaou M, Meeks KA, de-Graft Aikins A, Addo J, Amoah SK, et al. Food consumption, nutrient intake, and dietary patterns in Ghanaian migrants in Europe and their compatriots in Ghana. Food \& nutrition research. 2017;61(1):1341809.

32. Oti J, Eshun G. Dietary Habits and Nutritional Status of Undergraduate Students of Winneba Campus of University of Education, Winneba, Ghana. Jou Food Sci\&Nutri: JFSN-109 DOI: 1046715/jfsn2020. 2020;10.

33. Dwomoh D, Amuasi S, Agyabeng K, Incoom G, Alhassan Y, Yawson AE. Understanding the determinants of infant and under-five mortality rates: a multivariate decomposition analysis of Demographic and Health Surveys in Ghana, 2003, 2008 and 2014 . BMJ Global Health. 2019;4(4):e001658.

34. Ghana Statistical Service (GSS), Ghana Health Service (GHS), ICF M. Ghana Demographic and Health Survey 2009. Rockville, Maryland, USA: GSS, GHS, and ICF; 2009.

35. Brookhart MA, Schneeweiss S, Rothman KJ, Glynn RJ, Avorn J, Stürmer T. Variable selection for propensity score models. American journal of epidemiology. 2006;163(12):1149-56.

36. Stuart EA. Matching methods for causal inference: A review and a look forward. Statistical science: a review journal of the Institute of Mathematical Statistics. 2010;25(1):1.

37. StataCorp L. Stata statistical software: Release 13. 2013.

38. Ghana Statistical Service. Ghana Demographic and Health Survey 2008. Report. 2009.

39. Seward N, Osrin D, Li L, Costello A, Pulkki-Brännström A-M, Houweling TA, et al. Association between clean delivery kit use, clean delivery practices, and neonatal survival: pooled analysis of data from three sites in South Asia. PLoS medicine. 2012;9(2):e1001180.

40. Messeret ES, Masresha B, Yakubu A, Daniel F, Mihigo R, Nshimirimana D, et al. Maternal and Neonatal Tetanus Elimination (MNTE) in The WHO African Region. Journal of immunological sciences. 2018(15):103.

41. Shifa GT, Ahmed AA, Yalew AW. Maternal and child characteristics and health practices affecting under-five mortality: A matched case control study in Gamo Gofa Zone, Southern Ethiopia. PLoS ONE. 2018;13(8):1-17.

42. Issaka Al, Agho KE, Renzaho AMN. The Impact of Internal Migration on under-Five Mortality in 27 Sub-Saharan African Countries. PLoS ONE. 2016;11(10):1-16.

43. Millogo O, Doamba JEO, Sié A, Utzinger J, Vounatsou P. Geographical variation in the association of child, maternal and household health interventions with under-five mortality in Burkina Faso. PLoS ONE. 2019;14(7):1-17.

44. Edmond KM, Zandoh C, Quigley MA, Amenga-Etego S, Owusu-Agyei S, Kirkwood BR. Delayed breastfeeding initiation increases risk of neonatal mortality. Pediatrics. 2006;117(3):e380-e6.

45. Raihana S, Dibley MJ, Rahman MM, Tahsina T, Siddique MAB, Rahman QS, et al. Early initiation of breastfeeding and severe illness in the early newborn period: An observational study in rural Bangladesh. PLoS Medicine. 2019;16(8):1-17.

46. Nambuusi BB, Ssempiira J, Makumbi FE, Utzinger J, Kasasa S, Vounatsou P. Geographical variations of the associations between health interventions and all-cause under-five mortality in Uganda. BMC Public Health. 2019;19(1):1330-

47. Abdullah A, Hort K, Butu Y, Simpson L. Risk factors associated with neonatal deaths: a matched case-control study in Indonesia. Global health action. 2016;9(1):30445.

48. Clemens J, Elyazeed RA, Rao M, MEngg M, Savarino S, Morsy BZ, et al. Early initiation of breastfeeding and the risk of infant diarrhea in rural Egypt. Pediatrics. 1999;104(1):e3-e.

49. Page A-L, Hustache S, Luquero FJ, Djibo A, Manzo ML, Grais RF. Health care seeking behavior for diarrhea in children under 5 in rural Niger: results of a cross-sectional survey. BMC public health. 2011;11(1):389.

50. Blanchet NJ, Fink G, Osei-Akoto I. The effect of Ghana's National Health Insurance Scheme on health care utilisation. Ghana Med J. 2012;46(2):76-84.

51. Krumkamp R, Sarpong N, Kreuels B, Ehlkes L, Loag W, Schwarz NG, et al. Health care utilization and symptom severity in Ghanaian children-a cross-sectional study. PLoS One. 2013;8(11):e80598.

52. Bosomprah S, Ragno PL, Gros C, Banskota H. Health insurance and maternal, newborn services utilisation and under-five mortality. Archives of Public Health. 2015;73(1):51.

53. Liu L, Oza S, Hogan D, Chu Y, Perin J, Zhu J, et al. Global, regional, and national causes of under-5 mortality in 2000-15: an updated systematic analysis with implications for the Sustainable Development Goals. The Lancet. 2016;388(10063):3027-35.

54. Kanmiki EW, Bawah AA, Agorinya I, Achana FS, Awoonor-Williams JK, Oduro AR, et al. Socio-economic and demographic determinants of under-five mortality in rural northern Ghana. BMC international health and human rights. 2014;14(1):24.

55. Omariba DWR, Boyle MH. Family structure and child mortality in sub-Saharan Africa: Cross-national effects of polygyny. Journal of marriage and family. 2007;69(2):528-43.

56. Arthi V, Fenske J. Polygamy and child mortality: Historical and modern evidence from Nigeria's Igbo. Review of Economics of the Household. 2018;16(1):97-141.

Page $10 / 26$ 
57. Kozuki N, Lee AC, Silveira MF, Victora CG, Adair L, Humphrey J, et al. The associations of birth intervals with small-for-gestational-age, preterm, and neonatal and infant mortality: a meta-analysis. BMC public health. 2013;13(3):S3.

58. Nakamura H, Ikeda N, Stickley A, Mori R, Shibuya K. Achieving MDG 4 in sub-Saharan Africa: what has contributed to the accelerated child mortality decline in Ghana? PloS one. 2011;6(3):e17774.

59. Nesbitt RC, Lohela TJ, Manu A, Vesel L, Okyere E, Edmond K, et al. Quality along the continuum: a health facility assessment of intrapartum and postnatal care in Ghana. PloS one. 2013;8(11):e81089.

60. Singh K, Brodish P, Suchindran C. A regional multilevel analysis: can skilled birth attendants uniformly decrease neonatal mortality? Maternal and child health journal. 2014;18(1):242-9.

61. World Health Organization. Validation of maternal and neonatal tetanus elimination in Ghana, 2011. 2012;87(15):145-52.

62. Chowdhury AH. Determinants of under-five mortality in Bangladesh. 2013.

\section{Tables}

Table 1: Before and after matching sample size and imbalance by intervention among children 0-59 months 


\begin{tabular}{|c|c|c|c|c|c|c|c|c|c|c|c|c|c|c|}
\hline \multicolumn{8}{|l|}{ Before matching } & \multicolumn{7}{|c|}{ After matching } \\
\hline \multicolumn{15}{|c|}{ Early initiation of breastfeeding } \\
\hline \multirow[t]{2}{*}{ Sample size } & \multicolumn{7}{|c|}{ Unexposed =11,111 } & \multicolumn{7}{|c|}{ Unexposed=11,054 } \\
\hline & \multicolumn{7}{|c|}{ Exposed=12,467 } & \multicolumn{7}{|c|}{ Exposed $=12,467$} \\
\hline \multicolumn{15}{|c|}{ Summary of imbalance } \\
\hline Overall imbalance & \multicolumn{7}{|l|}{$\mathrm{L} 1=0.19$} & \multicolumn{7}{|c|}{$\mathrm{L} 1=6.00 \times 10^{-15}$} \\
\hline $\begin{array}{l}\text { Pre-treatment } \\
\text { covariates }\end{array}$ & L1 & Mean & Min & $25 \%$ & $50 \%$ & $75 \%$ & Max & L1 & Mean & Min & $25 \%$ & $50 \%$ & $75 \%$ & Max \\
\hline Survey year & 0.00162 & 0.00162 & 0 & 0 & 0 & 0 & 0 & $\begin{array}{l}1.0 \\
\times 10^{-14}\end{array}$ & $\begin{array}{l}1.6 \times 10^{-} \\
14\end{array}$ & 0 & 0 & 0 & 0 & 0 \\
\hline Region & 0.04241 & -0.07083 & 0 & -1 & 0 & 0 & 0 & $\begin{array}{l}3.7 \\
\times 10^{-15}\end{array}$ & $\begin{array}{l}7.5 \times 10^{-} \\
15\end{array}$ & 0 & 0 & 0 & 0 & 0 \\
\hline Type of delivery & 0.05376 & -0.08216 & 0 & 0 & 0 & 0 & 0 & $\begin{array}{l}5.5 \\
\times 10^{-16}\end{array}$ & $\begin{array}{l}1.9 \times 10^{-} \\
16\end{array}$ & 0 & 0 & 0 & 0 & 0 \\
\hline Skilled delivery & 0.05376 & 0.05376 & 0 & 0 & 0 & 0 & 0 & $\begin{array}{l}1.2 \\
\times 10^{-14}\end{array}$ & $\begin{array}{l}1.8 \times 10^{-} \\
14\end{array}$ & 0 & 0 & 0 & 0 & 0 \\
\hline Polygamous home & 0.02893 & -0.02893 & 0 & 0 & 0 & 0 & 0 & $\begin{array}{l}3.9 \\
\times 10^{-15}\end{array}$ & $\begin{array}{l}5.4 \times 10^{-} \\
15\end{array}$ & 0 & 0 & 0 & 0 & \\
\hline $\begin{array}{l}\text { Antenatal care } \\
\text { visits }\end{array}$ & 0.2844 & 0.02844 & 0 & 0 & 0 & 0 & 0 & $\begin{array}{l}6.3 \\
\times 10^{-15}\end{array}$ & $\begin{array}{l}9.0 \times 10^{-} \\
15\end{array}$ & 0 & 0 & 0 & 0 & 0 \\
\hline \multicolumn{15}{|l|}{ Clean postnatal care } \\
\hline \multirow[t]{2}{*}{ Sample size } & \multicolumn{7}{|c|}{ Unexposed=19,445 } & \multicolumn{7}{|c|}{ Unexposed=18,256 } \\
\hline & \multicolumn{7}{|c|}{ Exposed=4,133 } & \multicolumn{7}{|c|}{ Exposed=4,132 } \\
\hline \multicolumn{15}{|c|}{ Summary of imbalance } \\
\hline Overall imbalance & \multicolumn{7}{|l|}{$\mathrm{L} 1=0.40$} & \multicolumn{7}{|c|}{$\mathrm{L} 1=1.77 \times 10^{-14}$} \\
\hline $\begin{array}{l}\text { Pre-treatment } \\
\text { covariates }\end{array}$ & $\mathrm{L} 1$ & Mean & Min & $25 \%$ & $50 \%$ & $75 \%$ & Max & L1 & Mean & Min & $25 \%$ & $50 \%$ & $75 \%$ & Max \\
\hline Survey year & 0.23675 & 0.23675 & 0 & 1 & 0 & 0 & 0 & $\begin{array}{l}6.6 \\
\times 10^{-15}\end{array}$ & $\begin{array}{l}-7.5 \\
\times 10^{-15}\end{array}$ & 0 & 0 & 0 & 0 & 0 \\
\hline Region & 0.15833 & -0.15151 & 0 & -1 & 0 & 0 & 0 & $\begin{array}{l}1.2 \\
\times 10^{-14}\end{array}$ & $\begin{array}{l}-3.0 \\
\times 10^{-14}\end{array}$ & 0 & 0 & 0 & 0 & 0 \\
\hline Religion & 0.08431 & 0.09842 & 0 & 1 & 0 & 1 & 0 & $\begin{array}{l}6.5 \\
\times 10^{-15}\end{array}$ & $\begin{array}{l}-2.2 \\
\times 10^{-14}\end{array}$ & 0 & 0 & 0 & 0 & 0 \\
\hline Ethnicity & 0.16137 & 0.41236 & 0 & 0 & 0 & 0 & 0 & $\begin{array}{l}1.5 \\
\times 10^{-14}\end{array}$ & $\begin{array}{l}-9.1 \\
\times 10^{-14}\end{array}$ & 0 & 0 & 0 & 0 & 0 \\
\hline $\begin{array}{l}\text { Antenatal care } \\
\text { visits }\end{array}$ & 0.10669 & 0.10669 & 0 & 0 & 0 & 0 & 0 & $\begin{array}{l}8.5 \\
\times 10^{-15}\end{array}$ & $\begin{array}{l}1.1 \times 10^{-} \\
14\end{array}$ & 0 & 0 & 0 & 0 & 0 \\
\hline \multicolumn{15}{|c|}{ Hygienic disposal of stool } \\
\hline \multirow[t]{2}{*}{ Sample size } & \multicolumn{7}{|c|}{ Unexposed=14,026 } & \multicolumn{7}{|c|}{ Unexposed=13,919 } \\
\hline & \multicolumn{7}{|c|}{ Exposed $=9,552$} & \multicolumn{7}{|c|}{ Exposed=9,544 } \\
\hline \multicolumn{15}{|c|}{ Summary of imbalance } \\
\hline Overall imbalance & $\mathrm{L} 1=0.34$ & & & & & & & $\mathrm{~L} 1=5.5$ & $10^{-15}$ & & & & & \\
\hline $\begin{array}{l}\text { Pre-treatment } \\
\text { covariates }\end{array}$ & L1 & Mean & Min & $25 \%$ & $50 \%$ & $75 \%$ & Max & L1 & Mean & Min & $25 \%$ & $50 \%$ & $75 \%$ & Max \\
\hline
\end{tabular}




\begin{tabular}{|c|c|c|c|c|c|c|c|c|c|c|c|c|c|c|}
\hline Survey year & 0.12018 & -0.12018 & 0 & 0 & 0 & 0 & 0 & $\begin{array}{l}6.5 \\
\times 10^{-15}\end{array}$ & $\begin{array}{l}1.0 \times 10^{-} \\
14\end{array}$ & 0 & 0 & 0 & 0 & 0 \\
\hline Region & 0.19788 & 0.32124 & 0 & 1 & 0 & 0 & 0 & $\begin{array}{l}5.2 \\
\times 10^{-15}\end{array}$ & $\begin{array}{l}-2.6 \\
\times 10^{-15}\end{array}$ & 0 & 0 & 0 & 0 & 0 \\
\hline Wealth & 0.15875 & 0.47174 & 0 & 1 & 1 & 1 & 0 & $\begin{array}{l}1.4 \\
\times 10^{-14}\end{array}$ & $\begin{array}{l}-7.1 \\
\times 10^{-15}\end{array}$ & 0 & 0 & 0 & 0 & 0 \\
\hline Maternal education & 0.12856 & 0.23971 & 0 & 1 & 1 & 0 & 0 & $\begin{array}{l}1.4 \\
\times 10^{-14}\end{array}$ & $\begin{array}{l}-7.3 \\
\times 10^{-15}\end{array}$ & 0 & 0 & 0 & 0 & 0 \\
\hline Birth order & 0.02097 & -0.02097 & 0 & 0 & 0 & 0 & 0 & $\begin{array}{l}3.3 \\
\times 10^{-15}\end{array}$ & $\begin{array}{l}-5.4 \\
\times 10^{-15}\end{array}$ & 0 & 0 & 0 & 0 & 0 \\
\hline \multicolumn{15}{|l|}{ Iron intake } \\
\hline \multirow[t]{2}{*}{ Sample size } & \multicolumn{7}{|c|}{ Unexposed=12,231 } & \multicolumn{7}{|c|}{ Unexposed=12,121 } \\
\hline & \multicolumn{7}{|c|}{ Exposed=11,347 } & \multicolumn{7}{|c|}{ Exposed $=11,324$} \\
\hline \multicolumn{15}{|c|}{ Summary of imbalance } \\
\hline Overall imbalance & \multicolumn{7}{|l|}{ L1=0.34 } & \multicolumn{7}{|c|}{$L 1=2.27 \times 10^{-14}$} \\
\hline $\begin{array}{l}\text { Pre-treatment } \\
\text { covariates }\end{array}$ & L1 & Mean & Min & $25 \%$ & $50 \%$ & $75 \%$ & Max & L1 & Mean & Min & $25 \%$ & $50 \%$ & $75 \%$ & Max \\
\hline Survey year & 0.10953 & 0.10953 & 0 & 0 & 0 & 0 & 0 & $\begin{array}{l}7.7 \\
\times 10^{-15}\end{array}$ & $\begin{array}{l}-4.7 \\
\times 10^{-15}\end{array}$ & 0 & 0 & 0 & 0 & 0 \\
\hline Region & 0.08075 & 0.09709 & 0 & 1 & 0 & 0 & 0 & $\begin{array}{l}2.5 \\
x 10^{-14}\end{array}$ & $\begin{array}{l}5.5 \times 10^{-} \\
14\end{array}$ & 0 & 0 & 0 & 0 & 0 \\
\hline Wealth & 0.12794 & 0.44784 & 0 & 1 & 1 & 1 & 0 & $\begin{array}{l}2.7 \\
\times 10^{-14}\end{array}$ & $\begin{array}{l}1.5 \times 10^{-} \\
14\end{array}$ & 0 & 0 & 0 & 0 & 0 \\
\hline Birth interval & 0.00866 & -0.00866 & 0 & 0 & 0 & 0 & 0 & $\begin{array}{l}1.7 \\
\times 10^{-15}\end{array}$ & $\begin{array}{l}3.0 \times 10^{-} \\
15\end{array}$ & 0 & 0 & 0 & 0 & . \\
\hline $\begin{array}{l}\text { Antenatal care } \\
\text { visits }\end{array}$ & 0.28164 & 0.28164 & 0 & 1 & 0 & 0 & 0 & $\begin{array}{l}1.6 \\
x 10^{-14}\end{array}$ & $\begin{array}{l}3.0 \times 10^{-} \\
14\end{array}$ & 0 & 0 & 0 & 0 & 0 \\
\hline \multicolumn{15}{|l|}{ Antenatal care visits } \\
\hline \multirow[t]{2}{*}{ Sample size } & \multicolumn{7}{|c|}{ Unexposed $=4733$} & \multicolumn{7}{|c|}{ Unexposed $=4,730$} \\
\hline & \multicolumn{7}{|c|}{ Exposed=18,845 } & \multicolumn{7}{|c|}{ Exposed $=18,487$} \\
\hline \multicolumn{15}{|c|}{ Summary of imbalance } \\
\hline Overall imbalance & \multicolumn{7}{|l|}{$L 1=0.36$} & \multicolumn{7}{|c|}{$\mathrm{L} 1=1.56 \times 10^{-14}$} \\
\hline $\begin{array}{l}\text { Pre-treatment } \\
\text { covariates }\end{array}$ & L1 & Mean & Min & $25 \%$ & $50 \%$ & $75 \%$ & Max & L1 & Mean & Min & $25 \%$ & $50 \%$ & $75 \%$ & Max \\
\hline Survey year & 0.13881 & 0.13881 & 0 & 0 & 0 & 0 & 0 & $\begin{array}{l}8.9 \\
\times 10^{-15}\end{array}$ & $\begin{array}{l}-8.5 \\
\times 10^{-15}\end{array}$ & 0 & 0 & 0 & 0 & 0 \\
\hline NHIS & 0.17744 & 0.17744 & 0 & 0 & 1 & 0 & 0 & $\begin{array}{l}1.3 \\
\times 10^{-14}\end{array}$ & $\begin{array}{l}-1.4 \\
\times 10^{-14}\end{array}$ & 0 & 0 & 0 & 0 & 0 \\
\hline Birth interval & 0.03804 & -0.03804 & 0 & 0 & 0 & 0 & 0 & $\begin{array}{l}3.7 \\
\times 10^{-15}\end{array}$ & $\begin{array}{l}-1.7 \\
\times 10^{-15}\end{array}$ & 0 & 0 & 0 & 0 & 0 \\
\hline Wealth & 0.228 & 0.74224 & 0 & 1 & 1 & 1 & 0 & $\begin{array}{l}1.8 \\
\times 10^{-14}\end{array}$ & $\begin{array}{l}-1.5 \\
\times 10^{-15}\end{array}$ & 0 & 0 & 0 & 0 & 0 \\
\hline Maternal education & 0.24472 & 0.41287 & 0 & 1 & 1 & 0 & 0 & $\begin{array}{l}1.9 \\
\times 10^{-14}\end{array}$ & $\begin{array}{l}-9.1 \\
\times 10^{-15}\end{array}$ & 0 & 0 & 0 & 0 & 0 \\
\hline \multicolumn{15}{|l|}{ Skilled delivery } \\
\hline Sample size & Unexpose & $=6,949$ & & & & & & Unexpo & $d=6,921$ & & & & & \\
\hline
\end{tabular}




\section{Summary of imbalance}

\begin{tabular}{|c|c|c|c|c|c|c|c|c|c|c|c|c|c|c|}
\hline Overall imbalance & $\mathrm{L} 1=0.42$ & & & & & & & $L 1=1.1$ & $10^{-15}$ & & & & & \\
\hline $\begin{array}{l}\text { Pre-treatment } \\
\text { covariates }\end{array}$ & L1 & Mean & Min & $25 \%$ & $50 \%$ & $75 \%$ & Max & L1 & Mean & Min & $25 \%$ & $50 \%$ & $75 \%$ & Max \\
\hline Survey year & 0.15648 & 0.15642 & 0 & 0 & 0 & 0 & 0 & $\begin{array}{l}4.7 \\
\times 10^{-15}\end{array}$ & $\begin{array}{l}7.1 \times 10^{-} \\
15\end{array}$ & 0 & 0 & 0 & 0 & 0 \\
\hline Region & 0.19871 & 0.26338 & 0 & 1 & 0 & 0 & 0 & $\begin{array}{l}6.1 \\
\times 10^{-15}\end{array}$ & $\begin{array}{l}3.3 \times 10^{-} \\
14\end{array}$ & 0 & 0 & 0 & 0 & 0 \\
\hline Birth order & 0.21196 & -0.21196 & 0 & 0 & 0 & -1 & 0 & $\begin{array}{l}6.9 \\
\times 10^{-15}\end{array}$ & $\begin{array}{l}1.9 \times 10^{-} \\
15\end{array}$ & 0 & 0 & 0 & 0 & 0 \\
\hline NHIS & 0.19274 & 0.19274 & 0 & 0 & 1 & 0 & 0 & $\begin{array}{l}1.0 \\
\times 10^{-15}\end{array}$ & $\begin{array}{l}9.4 \times 10^{-} \\
15\end{array}$ & 0 & 0 & 0 & 0 & 0 \\
\hline $\begin{array}{l}\text { Antenatal care } \\
\text { visits }\end{array}$ & 0.28138 & 0.28138 & 0 & 1 & 0 & 0 & 0 & $\begin{array}{l}1.3 \\
\times 10^{-15}\end{array}$ & $\begin{array}{l}2.2 \times 10^{-} \\
15\end{array}$ & 0 & 0 & 0 & 0 & 0 \\
\hline Multiple birth & 0.01721 & 0.01721 & 0 & 0 & 0 & 0 & 0 & $\begin{array}{l}3.5 \\
\times 10^{-16}\end{array}$ & $\begin{array}{l}4.2 \times 10^{-} \\
17\end{array}$ & 0 & 0 & 0 & 0 & 0 \\
\hline
\end{tabular}

\section{Tetanus toxoid vaccine}

Sample size Unexposed $=6,783$

Exposed $=16,795$
Unexposed $=6,564$

Exposed $=16,456$

\section{Summary of imbalance}

\begin{tabular}{|c|c|c|c|c|c|c|c|c|c|c|c|c|c|c|}
\hline \multirow{2}{*}{$\begin{array}{l}\text { Overall imbalance } \\
\text { Pre-treatment } \\
\text { covariates }\end{array}$} & \multicolumn{7}{|l|}{$L 1=0.36$} & \multicolumn{7}{|c|}{$\mathrm{L} 1=7.25 \times 10^{-15}$} \\
\hline & L1 & Mean & Min & $25 \%$ & $50 \%$ & $75 \%$ & Max & L1 & Mean & Min & $25 \%$ & $50 \%$ & $75 \%$ & Max \\
\hline Survey year & 0.10031 & 0.10031 & 0 & 0 & 0 & 0 & 0 & $\begin{array}{l}5.2 \\
\times 10^{-15}\end{array}$ & $\begin{array}{l}-5.3 \\
\times 10^{-15}\end{array}$ & 0 & 0 & 0 & 0 & 0 \\
\hline Wealth & 0.12078 & 0.39223 & 0 & 1 & 1 & 1 & 0 & $\begin{array}{l}6.0 \\
\times 10^{-15}\end{array}$ & $\begin{array}{l}-3.6 \\
\times 10^{-14}\end{array}$ & 0 & 0 & 0 & 0 & 0 \\
\hline $\begin{array}{l}\text { Rural/urban } \\
\text { residence }\end{array}$ & 0.11253 & 0.17621 & 0 & 1 & 1 & 0 & 0 & $\begin{array}{l}5.6 \\
\times 10^{-15}\end{array}$ & $\begin{array}{l}-5.8 \\
\times 10^{-14}\end{array}$ & 0 & 0 & 0 & 0 & 0 \\
\hline Maternal education & 0.06607 & -0.06607 & 0 & 0 & 0 & 0 & 0 & $\begin{array}{l}7.0 \\
\times 10^{-15}\end{array}$ & $\begin{array}{l}-1.3 \\
\times 10^{-15}\end{array}$ & 0 & 0 & 0 & 0 & 0 \\
\hline NHIS status & 0.06553 & 0.0655 & 0 & 0 & 1 & 0 & 0 & $\begin{array}{l}4.6 \\
\times 10^{-15}\end{array}$ & $\begin{array}{l}-3.0 \\
\times 10^{-15}\end{array}$ & 0 & 0 & 0 & 0 & 0 \\
\hline $\begin{array}{l}\text { Antenatal care } \\
\text { visits }\end{array}$ & 0.24223 & 0.24223 & 0 & 1 & 0 & 0 & 0 & $\begin{array}{l}4.1 \\
\times 10^{-15}\end{array}$ & $\begin{array}{l}-6.6 \\
x 10^{-15}\end{array}$ & 0 & 0 & 0 & 0 & 0 \\
\hline \multicolumn{15}{|c|}{ Intermittent preventive treatment of malaria in pregnancy (IPT-p) } \\
\hline \multirow[t]{2}{*}{ Sample size } & \multicolumn{7}{|c|}{ Unexposed $=9,840$} & \multicolumn{7}{|c|}{ Unexposed=9,435 } \\
\hline & \multicolumn{7}{|c|}{ Exposed=13,738 } & \multicolumn{7}{|c|}{ Exposed $=13,550$} \\
\hline \multicolumn{15}{|c|}{ Summary of imbalance } \\
\hline Overall imbalance & \multicolumn{7}{|l|}{$L 1=0.46$} & \multicolumn{7}{|c|}{$\mathrm{L} 1=6.28 \times 10^{-16}$} \\
\hline $\begin{array}{l}\text { Pre-treatment } \\
\text { covariates }\end{array}$ & L1 & Mean & Min & $25 \%$ & $50 \%$ & $75 \%$ & Max & L1 & Mean & Min & $25 \%$ & $50 \%$ & $75 \%$ & Max \\
\hline Survey year & 0.24622 & 0.24622 & 0 & 1 & 0 & 0 & 0 & $\begin{array}{l}4.1 \\
\times 10^{-15}\end{array}$ & $\begin{array}{l}7.4 \times 10^{-} \\
15\end{array}$ & 0 & 0 & 0 & 0 & 0 \\
\hline
\end{tabular}




\begin{tabular}{|c|c|c|c|c|c|c|c|c|c|c|c|c|c|c|}
\hline Region & 0.663 & 0.06868 & 0 & 1 & 0 & 0 & 0 & $\begin{array}{l}1.8 \\
\times 10^{-15}\end{array}$ & $\begin{array}{l}-1.3 \\
\times 10^{-14}\end{array}$ & 0 & 0 & 0 & 0 & 0 \\
\hline Wealth & 0.0764 & 0.14731 & 0 & 1 & 1 & 0 & 0 & $\begin{array}{l}2.8 \\
\times 10^{-15}\end{array}$ & $\begin{array}{l}2.3 \times 10^{-} \\
14\end{array}$ & 0 & 0 & 0 & 0 & 0 \\
\hline Maternal education & 0.0809 & 0.15081 & 0 & 1 & 1 & 0 & 0 & $\begin{array}{l}4.3 \\
\times 10^{-15}\end{array}$ & $\begin{array}{l}2.0 \times 10^{-} \\
14\end{array}$ & 0 & 0 & 0 & 0 & 0 \\
\hline NHIS status & 0.13546 & 0.13546 & 0 & 0 & 1 & 0 & 0 & $\begin{array}{l}3.4 \\
\times 10^{-15}\end{array}$ & $\begin{array}{l}6.3 \times 10^{-} \\
15\end{array}$ & 0 & 0 & 0 & 0 & 0 \\
\hline $\begin{array}{l}\text { Antenatal care } \\
\text { visits }\end{array}$ & 0.23336 & 0.23336 & 0 & 1 & 0 & 0 & 0 & $\begin{array}{l}9.5 \\
\times 10^{-15}\end{array}$ & $\begin{array}{l}1.7 \times 10^{-} \\
14\end{array}$ & 0 & 0 & 0 & 0 & 0 \\
\hline
\end{tabular}

Note: L1=0 means perfect covariate balance between treated and untreated groups. L1=1 means complete incompatible treatment and comparison groups with respect of covariates. The closer the values of $L 1$ to zero, the better the covariate balance.

Table 2: Adjusted odds ratios of interventions with causal effect on under-five mortality, multiple logistic regression analysis 


\begin{tabular}{|c|c|c|c|c|c|c|c|c|}
\hline $\begin{array}{l}\text { Covariates } \\
\text { adjusted for in } \\
\text { the model }\end{array}$ & $\begin{array}{l}\text { Antenatal } \\
\text { care visits }\end{array}$ & $\begin{array}{l}\text { Skilled } \\
\text { delivery }\end{array}$ & Iron intake & $\begin{array}{l}\text { Early } \\
\text { initiation of } \\
\text { breastfeeding }\end{array}$ & $\begin{array}{l}\text { Clean } \\
\text { postnatal } \\
\text { care }\end{array}$ & IPT-p & $\begin{array}{l}\text { Hygienic } \\
\text { disposal of } \\
\text { stool }\end{array}$ & $\begin{array}{l}\text { Tetanus } \\
\text { toxoid } \\
\text { vaccine }\end{array}$ \\
\hline Survey year & aOR $(95 \% \mathrm{Cl})$ & aOR $(95 \% \mathrm{Cl})$ & aOR $(95 \% \mathrm{Cl})$ & aOR $(95 \% \mathrm{Cl})$ & aOR $(95 \% \mathrm{Cl})$ & $\begin{array}{l}\mathrm{aOR} \\
(95 \% \mathrm{Cl})\end{array}$ & aOR $(95 \% \mathrm{Cl})$ & $\begin{array}{l}\mathrm{aOR} \\
(95 \% \mathrm{Cl})\end{array}$ \\
\hline \multicolumn{9}{|l|}{2008} \\
\hline 2014 & $\begin{array}{l}0.95(0.49- \\
1.84)\end{array}$ & $\begin{array}{l}1.04(0.56- \\
1.95)\end{array}$ & $\begin{array}{l}0.86(0.42- \\
1.79)\end{array}$ & $\begin{array}{l}1.00(0.52- \\
1.90)\end{array}$ & $\begin{array}{l}0.65(0.32- \\
1.31)\end{array}$ & $\begin{array}{l}1.74(0.79- \\
3.82)\end{array}$ & $\begin{array}{l}1.49(0.60- \\
3.67)\end{array}$ & $\begin{array}{l}0.99(0.53- \\
1.86)\end{array}$ \\
\hline \multicolumn{9}{|l|}{ Age(months) } \\
\hline \multicolumn{9}{|l|}{$<1$} \\
\hline 1 to 5 & $\begin{array}{l}0.01(0.01- \\
0.03)^{\star \star \star *}\end{array}$ & $\begin{array}{l}0.01(0.01- \\
0.03)^{\star \star \star *}\end{array}$ & $\begin{array}{l}0.01(0.003- \\
0.03)^{\star \star \star}\end{array}$ & $\begin{array}{l}0.02(0.01- \\
\left.0.05^{\star \star \star}\right)\end{array}$ & $\begin{array}{l}0.01(0.003- \\
0.02)^{\star \star \star}\end{array}$ & $\begin{array}{l}0.005(0.70- \\
3.11)^{\star \star \star *}\end{array}$ & $\begin{array}{l}0.01(0.01- \\
0.04)^{\star \star \star}\end{array}$ & $\begin{array}{l}0.02(0.01- \\
0.04)^{\star \star \star}\end{array}$ \\
\hline 6 to 11 & $\begin{array}{l}0.02(0.01- \\
0.04)\end{array}$ & $\begin{array}{l}0.02(0.01- \\
0.04)\end{array}$ & $\begin{array}{l}0.01(0.004- \\
0.03)\end{array}$ & $\begin{array}{l}0.02(0.01- \\
0.05)\end{array}$ & $\begin{array}{l}0.01(0.002- \\
0.03)\end{array}$ & $\begin{array}{l}0.01(0.91- \\
4.73)\end{array}$ & $\begin{array}{l}0.01(0.004- \\
0.03)\end{array}$ & $\begin{array}{l}0.02(0.01- \\
0.05)\end{array}$ \\
\hline >=12 months & $\begin{array}{l}0.004(0.001- \\
0.01)\end{array}$ & $\begin{array}{l}0.004(0.002- \\
0.01)\end{array}$ & $\begin{array}{l}0.004(0.001- \\
0.01)\end{array}$ & $\begin{array}{l}0.01(0.002- \\
0.02)\end{array}$ & $\begin{array}{l}0.002(0.001- \\
0.01)\end{array}$ & $\begin{array}{l}0.002(0.64- \\
12.81)\end{array}$ & $\begin{array}{l}0.002(0.01- \\
0.01)\end{array}$ & $\begin{array}{l}0.02(0.002- \\
0.01)\end{array}$ \\
\hline \multicolumn{9}{|l|}{ Gender } \\
\hline \multicolumn{9}{|l|}{ Male } \\
\hline Female & $\begin{array}{l}0.93(0.49- \\
1.77)\end{array}$ & $\begin{array}{l}1.00(0.54- \\
1.88)\end{array}$ & $\begin{array}{l}1.00(0.43- \\
2.31)\end{array}$ & $\begin{array}{l}0.90(0.50- \\
1.63)\end{array}$ & $\begin{array}{l}0.89(0.40- \\
2.00)\end{array}$ & $\begin{array}{l}1.61(0.76- \\
3.41)\end{array}$ & $\begin{array}{l}1.14(0.23- \\
2.24)\end{array}$ & $\begin{array}{l}0.84(0.46- \\
1.52)\end{array}$ \\
\hline \multicolumn{9}{|l|}{ Birth interval } \\
\hline \multicolumn{9}{|l|}{$>=2$ years } \\
\hline Less than 2 & $\begin{array}{l}1.76(0.80- \\
3.86)\end{array}$ & $\begin{array}{l}2.40(1.19- \\
4.84)^{\star}\end{array}$ & $\begin{array}{l}1.38(0.67- \\
2.85)\end{array}$ & $\begin{array}{l}2.58(1.27- \\
5.25)^{\star}\end{array}$ & $\begin{array}{l}2.87(1.37- \\
6.02)^{\star \star}\end{array}$ & $\begin{array}{l}1.48(0.70- \\
3.11)\end{array}$ & $\begin{array}{l}1.32(0.60- \\
2.90)\end{array}$ & $\begin{array}{l}2.23(1.10- \\
4.55)^{\star}\end{array}$ \\
\hline \multicolumn{9}{|l|}{ Birth order } \\
\hline \multicolumn{9}{|l|}{ Below 3} \\
\hline$>=3$ & $\begin{array}{l}1.73(0.82- \\
3.65)\end{array}$ & $\begin{array}{l}2.15(1.04- \\
4.47)^{\star}\end{array}$ & $\begin{array}{l}1.07(0.47- \\
2.44)\end{array}$ & $\begin{array}{l}1.90(0.91- \\
3.98)\end{array}$ & $\begin{array}{l}2.41(1.12- \\
5.16)^{\star}\end{array}$ & $\begin{array}{l}2.08(0.91- \\
4.73)\end{array}$ & $\begin{array}{l}1.19(0.48- \\
2.92)\end{array}$ & $\begin{array}{l}1.60(0.77- \\
3.34)\end{array}$ \\
\hline \multicolumn{9}{|l|}{ Birth weight } \\
\hline \multicolumn{9}{|l|}{ Normal } \\
\hline Small & $\begin{array}{l}0.88(0.38- \\
2.04)\end{array}$ & $\begin{array}{l}1.24(0.53- \\
2.94)\end{array}$ & $\begin{array}{l}0.74(0.28- \\
2.00)\end{array}$ & $\begin{array}{l}0.80(0.31- \\
2.08)\end{array}$ & $\begin{array}{l}0.71(0.27- \\
1.86)\end{array}$ & $\begin{array}{l}1.23(0.57- \\
2.71)\end{array}$ & $\begin{array}{l}0.71(0.23- \\
2.24)\end{array}$ & $\begin{array}{l}0.65(0.24- \\
1.76)\end{array}$ \\
\hline \multicolumn{9}{|l|}{ Multiple birth } \\
\hline \multicolumn{9}{|l|}{ No } \\
\hline Yes & $\begin{array}{l}5.99(1.34- \\
26.89)^{\star}\end{array}$ & $\begin{array}{l}0.79(0.08- \\
7.43)\end{array}$ & $\begin{array}{l}8.16(1.68- \\
39.54)^{\star}\end{array}$ & $\begin{array}{l}2.74(0.46- \\
16.30)\end{array}$ & $\begin{array}{l}1.54(0.29- \\
8.20)\end{array}$ & $\begin{array}{l}2.87(0.64- \\
12.81)\end{array}$ & $\begin{array}{l}37.65(10.53- \\
134.65)\end{array}$ & $\begin{array}{l}\text { 7.57(1.81- } \\
31.61)^{\star}\end{array}$ \\
\hline \multicolumn{9}{|l|}{ Delivery type } \\
\hline \multicolumn{9}{|l|}{ Vaginal } \\
\hline Caesarean & $\begin{array}{l}0.88(0.37- \\
2.11)\end{array}$ & $\begin{array}{l}0.74(0.33- \\
1.89)\end{array}$ & $\begin{array}{l}0.64(0.25- \\
1.63)\end{array}$ & $\begin{array}{l}0.98(0.38- \\
2.52)\end{array}$ & $\begin{array}{l}0.51(0.18- \\
1.48)\end{array}$ & $\begin{array}{l}0.39(0.14- \\
1.08)\end{array}$ & $\begin{array}{l}0.52(0.18- \\
1.50)\end{array}$ & $\begin{array}{l}0.83(0.32- \\
2.15)\end{array}$ \\
\hline \multicolumn{9}{|l|}{ Region } \\
\hline \multicolumn{9}{|l|}{ Northern belt } \\
\hline Middle belt & $\begin{array}{l}0.82(0.33- \\
2.04)\end{array}$ & $\begin{array}{l}0.53(0.23- \\
1.22)\end{array}$ & $\begin{array}{l}1.16(0.43- \\
3.12)\end{array}$ & $\begin{array}{l}0.64(0.29- \\
1.57)\end{array}$ & $\begin{array}{l}0.96(0.31- \\
3.02)\end{array}$ & $\begin{array}{l}0.63(0.21- \\
1.90)\end{array}$ & $\begin{array}{l}1.08(0.39- \\
3.03)\end{array}$ & $\begin{array}{l}0.75(0.31- \\
1.80)\end{array}$ \\
\hline Southern belt & $\begin{array}{l}9.42(0.14- \\
1.28)\end{array}$ & $\begin{array}{l}0.37(0.13- \\
1.06)\end{array}$ & $\begin{array}{l}0.65(0.19- \\
2.22)\end{array}$ & $\begin{array}{l}0.52(0.19- \\
1.47)\end{array}$ & $\begin{array}{l}0.91(0.24- \\
3.46)\end{array}$ & $\begin{array}{l}0.31(0.08- \\
1.30)\end{array}$ & $\begin{array}{l}0.39(0.10- \\
1.59)\end{array}$ & $\begin{array}{l}0.39(0.14- \\
1.10)\end{array}$ \\
\hline \multicolumn{9}{|l|}{$\begin{array}{l}\text { Urban/rural } \\
\text { residence }\end{array}$} \\
\hline
\end{tabular}




\begin{tabular}{|c|c|c|c|c|c|c|c|c|}
\hline Rural & $\begin{array}{l}1.15(0.48- \\
2.80)\end{array}$ & $\begin{array}{l}0.82(0.32- \\
2.11)\end{array}$ & $\begin{array}{l}0.89(0.36- \\
2.18)\end{array}$ & $\begin{array}{l}0.87(0.36- \\
2.09)\end{array}$ & $\begin{array}{l}0.97(0.40- \\
2.38)\end{array}$ & $\begin{array}{l}1.67(0.54- \\
5.17)\end{array}$ & $\begin{array}{l}1.78(0.51- \\
6.21)\end{array}$ & $\begin{array}{l}1.09(0.39- \\
3.10)\end{array}$ \\
\hline \multicolumn{9}{|l|}{ Wealth quintile } \\
\hline \multicolumn{9}{|l|}{ Poorest } \\
\hline Poorer & $\begin{array}{l}0.822(0.27- \\
2.46)\end{array}$ & $\begin{array}{l}0.83(0.30- \\
2.32)\end{array}$ & $\begin{array}{l}0.91(0.28- \\
2.92)\end{array}$ & $\begin{array}{l}0.94(0.34- \\
2.66)\end{array}$ & $\begin{array}{l}1.54(0.36- \\
6.67)\end{array}$ & $\begin{array}{l}0.94(0.28- \\
3.16)\end{array}$ & $\begin{array}{l}0.62(0.21- \\
1.80)\end{array}$ & $\begin{array}{l}0.85(0.31- \\
2.34)\end{array}$ \\
\hline Middle & $\begin{array}{l}1.31(0.40- \\
4.26)\end{array}$ & $\begin{array}{l}1.64(0.52- \\
5.19)\end{array}$ & $\begin{array}{l}1.23(0.35- \\
4.35)\end{array}$ & $\begin{array}{l}1.16(0.33- \\
4.11)\end{array}$ & $\begin{array}{l}2.13(0.46- \\
9.83)\end{array}$ & $\begin{array}{l}4.66(1.09- \\
19.90)\end{array}$ & $\begin{array}{l}1.22(0.28- \\
5.32)\end{array}$ & $\begin{array}{l}1.19(0.37- \\
3.86)\end{array}$ \\
\hline Richer & $\begin{array}{l}0.75(0.16- \\
3.54)\end{array}$ & $\begin{array}{l}1.29(0.29- \\
5.84\end{array}$ & $\begin{array}{l}1.09(0.22- \\
5.37)\end{array}$ & $\begin{array}{l}0.85(0.19- \\
3.79)\end{array}$ & $\begin{array}{l}0.94(0.11- \\
8.30)\end{array}$ & $\begin{array}{l}1.07(0.15- \\
7.87)\end{array}$ & $\begin{array}{l}0.77(0.14- \\
4.06)\end{array}$ & $\begin{array}{l}1.05(0.20- \\
5.50)\end{array}$ \\
\hline Richest & $\begin{array}{l}1.32(0.22- \\
7.74)\end{array}$ & $\begin{array}{l}2.14(0.38- \\
11.92)\end{array}$ & $\begin{array}{l}1.25(0.21- \\
7.30)\end{array}$ & $\begin{array}{l}1.84(0.32- \\
10.56)\end{array}$ & $\begin{array}{l}3.98(0.31- \\
52.03)\end{array}$ & $\begin{array}{l}3.26(0.39- \\
26.83)\end{array}$ & $\begin{array}{l}1.12(0.16- \\
7.81)\end{array}$ & $\begin{array}{l}1.67(0.26- \\
10.94)\end{array}$ \\
\hline \multicolumn{9}{|l|}{$\begin{array}{l}\text { Polygamous } \\
\text { home }\end{array}$} \\
\hline \multicolumn{9}{|l|}{$\begin{array}{l}\text { Not } \\
\text { polygamous }\end{array}$} \\
\hline Polygamous & $\begin{array}{l}2.41(1.08- \\
5.32)^{\star}\end{array}$ & $\begin{array}{l}2.16(1.03- \\
4.56)^{\star}\end{array}$ & $\begin{array}{l}1.89(0.70- \\
5.07)\end{array}$ & $\begin{array}{l}2.95(1.42- \\
6.15)^{\star \star}\end{array}$ & $\begin{array}{l}3.33(1.37- \\
8.06)^{\star}\end{array}$ & $\begin{array}{l}1.69(0.71- \\
4.02)\end{array}$ & $\begin{array}{l}1.16(0.34- \\
3.92)\end{array}$ & $\begin{array}{l}2.08(1.03- \\
4.18)^{\star}\end{array}$ \\
\hline \multicolumn{9}{|l|}{$\begin{array}{l}\text { Household } \\
\text { size }\end{array}$} \\
\hline \multicolumn{9}{|l|}{$<6$} \\
\hline$>=6$ & $\begin{array}{l}1.49(0.68- \\
3.27)\end{array}$ & $\begin{array}{l}1.09(0.51- \\
2.34)\end{array}$ & $\begin{array}{l}2.07(0.92- \\
4.63)\end{array}$ & $\begin{array}{l}1.16(0.53- \\
2.54)\end{array}$ & $\begin{array}{l}1.51(0.72- \\
3.19)\end{array}$ & $\begin{array}{l}2.29(1.01- \\
5.17)^{\star}\end{array}$ & $\begin{array}{l}1.26(0.57- \\
2.79)\end{array}$ & $\begin{array}{l}1.24(0.58- \\
2.65)\end{array}$ \\
\hline \multicolumn{9}{|l|}{$\begin{array}{l}\text { No. of CU5 in } \\
\text { household }\end{array}$} \\
\hline \multicolumn{9}{|l|}{$1-2$} \\
\hline 3 and above & $\begin{array}{l}0.17(0.06- \\
0.49)^{\star \star}\end{array}$ & $\begin{array}{l}0.10(0.62- \\
0.53)^{\star \star}\end{array}$ & $\begin{array}{l}0.15(0.05- \\
0.49)^{\star \star}\end{array}$ & $\begin{array}{l}0.14(0.04- \\
0.46)^{\star}\end{array}$ & $\begin{array}{l}0.03(0.02- \\
0.21)^{\star \star \star}\end{array}$ & $\begin{array}{l}0.15(0.06- \\
0.40)^{\star \star \star}\end{array}$ & $\begin{array}{l}0.14(0.04- \\
0.48)^{\star \star}\end{array}$ & $\begin{array}{l}0.20(0.07- \\
0.53)^{\star \star}\end{array}$ \\
\hline \multicolumn{9}{|l|}{ Maternal age } \\
\hline \multicolumn{9}{|l|}{$<35$} \\
\hline$>=35$ & $\begin{array}{l}0.64(0.30- \\
1.36)\end{array}$ & $\begin{array}{l}0.75(0.36- \\
1.58)\end{array}$ & $\begin{array}{l}0.92(0.41- \\
2.09)\end{array}$ & $\begin{array}{l}0.57(0.26- \\
1.26)\end{array}$ & $\begin{array}{l}0.57(0.22- \\
1.43)\end{array}$ & $\begin{array}{l}0.42(0.21- \\
0.84)^{\star}\end{array}$ & $\begin{array}{l}0.33(0.12- \\
0.93)\end{array}$ & $\begin{array}{l}0.72(0.34- \\
1.53)\end{array}$ \\
\hline \multicolumn{9}{|l|}{$\begin{array}{l}\text { Maternal } \\
\text { education }\end{array}$} \\
\hline \multicolumn{9}{|l|}{ None } \\
\hline Primary & $\begin{array}{l}1.19(0.48- \\
2.98)\end{array}$ & $\begin{array}{l}1.24(0.50- \\
3.05)\end{array}$ & $\begin{array}{l}2.04(0.69- \\
6.08)\end{array}$ & $\begin{array}{l}1.26(0.49- \\
3.22)\end{array}$ & $\begin{array}{l}1.14(0.47- \\
2.78)\end{array}$ & $\begin{array}{l}0.60(0.23- \\
1.52)\end{array}$ & $\begin{array}{l}1.22(0.49- \\
3.07)\end{array}$ & $\begin{array}{l}1.06(0.42- \\
2.66)\end{array}$ \\
\hline $\begin{array}{l}\text { Secondary or } \\
\text { higher }\end{array}$ & $\begin{array}{l}0.60(0.21- \\
1.66)\end{array}$ & $\begin{array}{l}0.58(0.22- \\
1.56)\end{array}$ & $\begin{array}{l}0.71(0.26- \\
1.96)\end{array}$ & $\begin{array}{l}0.55(0.20- \\
1.52)\end{array}$ & $\begin{array}{l}0.80(0.32- \\
2.00)\end{array}$ & $\begin{array}{l}0.34(0.12- \\
0.95)\end{array}$ & $\begin{array}{l}0.62(0.20- \\
1.96)\end{array}$ & $\begin{array}{l}0.49(0.19- \\
1.28)\end{array}$ \\
\hline \multicolumn{9}{|l|}{ Married } \\
\hline \multicolumn{9}{|l|}{ Not Married } \\
\hline Married & $\begin{array}{l}0.64(0.29- \\
1.39)\end{array}$ & $\begin{array}{l}0.53(0.26- \\
1.07)\end{array}$ & $\begin{array}{l}0.68(0.27- \\
1.74)\end{array}$ & $\begin{array}{l}0.63(0.31- \\
1.30)\end{array}$ & $\begin{array}{l}0.66(0.30- \\
1.46)\end{array}$ & $\begin{array}{l}0.62(0.28- \\
1.37)\end{array}$ & $\begin{array}{l}0.72(0.28- \\
1.86)\end{array}$ & $\begin{array}{l}0.72(0.35- \\
1.49)\end{array}$ \\
\hline \multicolumn{9}{|l|}{ Religion } \\
\hline \multicolumn{9}{|l|}{ Orthodox } \\
\hline Pentecostal & $\begin{array}{l}0.87(0.39- \\
1.92)\end{array}$ & $\begin{array}{l}1.21(0.54- \\
2.70)\end{array}$ & $\begin{array}{l}0.61(0.21- \\
1.79)\end{array}$ & $\begin{array}{l}1.05(0.48- \\
2.33)\end{array}$ & $\begin{array}{l}0.94(0.38- \\
2.48)\end{array}$ & $\begin{array}{l}0.74(0.29- \\
1.93)\end{array}$ & $\begin{array}{l}0.55(0.21- \\
1.44)\end{array}$ & $\begin{array}{l}0.81(0.37- \\
1.78)\end{array}$ \\
\hline Islam & $\begin{array}{l}1.36(0.59- \\
3.70)\end{array}$ & $\begin{array}{l}1.96(0.76- \\
5.05)\end{array}$ & $\begin{array}{l}1.24(0.34- \\
4.50)\end{array}$ & $\begin{array}{l}1.91(0.71- \\
5.13)\end{array}$ & $\begin{array}{l}4.06(1.31- \\
12.65)\end{array}$ & $\begin{array}{l}2.43(0.84- \\
6.99)\end{array}$ & $\begin{array}{l}0.57(0.16- \\
2.05)\end{array}$ & $\begin{array}{l}1.34(0.53- \\
3.38)\end{array}$ \\
\hline Others & $1.19(0.35-$ & $1.89(0.58-$ & 1.01(0.18- & $2.00(0.56-$ & $1.83(0.45-$ & 3.7(0.95- & $0.89(0.26-$ & $1.30(0.41-$ \\
\hline
\end{tabular}

Page 17/26 
Ethnicity

Akan

\begin{tabular}{|c|c|c|c|c|c|c|c|c|}
\hline Mole-Dagbani & $\begin{array}{l}0.62(0.16- \\
2.32)\end{array}$ & $\begin{array}{l}0.78(0.24- \\
2.70)\end{array}$ & $\begin{array}{l}0.79(0.21- \\
3.01)\end{array}$ & $\begin{array}{l}0.54(0.16- \\
1.79)\end{array}$ & $\begin{array}{l}0.57(0.19- \\
2.03)\end{array}$ & $\begin{array}{l}0.49(0.12- \\
2.03)\end{array}$ & $\begin{array}{l}1.45(0.39- \\
5.37)\end{array}$ & $\begin{array}{l}0.64(0.29- \\
2.03)\end{array}$ \\
\hline Others & $\begin{array}{l}1.40(0.60- \\
3.26)\end{array}$ & $\begin{array}{l}1.33(0.62- \\
2.86)\end{array}$ & $\begin{array}{l}1.67(0.56- \\
4.99)\end{array}$ & $\begin{array}{l}1.00(0.45- \\
2.26)\end{array}$ & $\begin{array}{l}1.96(0.81- \\
4.75)\end{array}$ & $\begin{array}{l}1.14(0.49- \\
2.68)\end{array}$ & $\begin{array}{l}1.46(0.58- \\
3.75)\end{array}$ & $\begin{array}{l}1.30(0.58- \\
2.92)\end{array}$ \\
\hline
\end{tabular}

Mother's

employment

Not employed

Employed

$0.70(0.32-$

$0.67(0.31-$

$0.61(0.27-$

$0.86(0.40-$

1.38(0.57-

0.82(0.37-

$0.73(0.28-$

0.74(0.33-

1.50)

1.38)

3.63)

1.84)

1.91)

1.65)

\section{Contraceptives}

use

No use

Use

1.22(0.52-

2.89)

1.45(0.65-

0.83(0.31-

1.37(0.59-

1.49(0.59-

$3.79)$

$0.89(0.39-$

1.04(0.30-

1.43(0.64-

2.22)

3.19)

2.02)

3.58)

3.17)

Sanitation

Not improved

2.35)

$0.88(0.33-$

$0.52(0.18$

$0.88(0.23-$

$0.50(0.14-$

$0.57(0.18-$

$0.75(0.26-$

2.18)

$0.91(0.34-$

Antenatal

visits

$<4$ plus visits

4 + visit

1.78(0.80-

$0.74(0.35-$

1.04(0.32-

0.88(0.42-

1.01(0.40-

2.12(0.78-

1.14(0.45-

5.77)

2.88)

$0.88(0.40-$ 1.91)

Tetanus toxoid

vaccine

Not received

Received

0.83(0.39-

1.78)

$0.68(0.33-$

1.37)

1.45(0.55-

3.78)

0.58(0.27-

1.21)

$0.52(0.23-$

1.13)

$0.51(0.23-$

$1.78(0.79$

4.01)

$0.86(0.41-$

Skilled delivery

Not skilled

Skilled

1.45(0.55-

3.78)

$1.40(0.54-$

$1.68(0.61-$

1.61(0.66-

3.96)

1.63(0.51-

$5.16)$

2.32(0.83-

6.49)

$1.00(0.37$

2.70)

$1.70(0.68$

4.26)

Improved

water source

Not improved

Improved

1.41(0.61-

1.56(0.73-

3.32)

2.53(0.81-

1.31(0.60-

1.37(0.53-

3.52)

1.69)(0.63-

4.53)

1.09(0.42-

2.85)

1.32(0.61-

Water

connected

Not connected

Connected

$$
\begin{aligned}
& 0.95(0.25- \\
& 3.60)
\end{aligned}
$$

$0.58(0.18-$

$0.74(0.14$

$0.70(0.19-$
$2.57)$

$1.12(0.24-$
$5.18)$

$0.59(0.10$

$0.57(0.31$

2.44)

$0.63(0.17-$

ITN/IRS

protection

Not protected

Protected

$\begin{array}{ll}0.87(0.39- & 0.83(0.38- \\ 1.94) & 1.81)\end{array}$

$1.15(0.46-$

$0.79(0.37-$

$0.81(0.39-$

1.68)

$1.48(0.45-$

4.89)

$0.43(0.19-$

$0.96)$ *

$0.79(0.36-$

Page $18 / 26$ 


\begin{tabular}{|c|c|c|c|c|c|c|c|c|}
\hline $\begin{array}{l}\text { Hygienic } \\
\text { disposal of } \\
\text { stool }\end{array}$ & & & & & & & & \\
\hline Not hygienic & & & & & & & & \\
\hline Hygienic & $\begin{array}{l}0.61(0.31- \\
1.20)\end{array}$ & $\begin{array}{l}0.65(0.35- \\
1.20)\end{array}$ & $\begin{array}{l}0.58(0.26- \\
1.28)\end{array}$ & $\begin{array}{l}0.66(0.36- \\
1.22)\end{array}$ & $\begin{array}{l}0.52(0.24- \\
1.13)\end{array}$ & $\begin{array}{l}0.45(0.21- \\
0.95)^{\star}\end{array}$ & $\begin{array}{l}0.74(0.33- \\
1.66)\end{array}$ & $\begin{array}{l}0.62(0.33- \\
1.16)\end{array}$ \\
\hline $\begin{array}{l}\text { Early } \\
\text { breastfeeding }\end{array}$ & & & & & & & & \\
\hline $\begin{array}{l}\text { Not early } \\
\text { initiation }\end{array}$ & & & & & & & & \\
\hline Early initiation & $\begin{array}{l}0.40(0.20- \\
0.78)^{\star}\end{array}$ & $\begin{array}{l}0.37(0.20- \\
0.70)^{\star \star}\end{array}$ & $\begin{array}{l}0.45(0.18- \\
1.11)\end{array}$ & $\begin{array}{l}0.39(0.22- \\
0.71)^{\star \star \star}\end{array}$ & $\begin{array}{l}0.64(0.30- \\
1.37)\end{array}$ & $\begin{array}{l}0.22(0.10- \\
0.47)^{\star \star \star}\end{array}$ & $\begin{array}{l}0.37(0.51- \\
0.93)^{\star}\end{array}$ & $\begin{array}{l}0.42(0.22- \\
0.80)^{\star}\end{array}$ \\
\hline $\begin{array}{l}\text { Clean } \\
\text { postnatal care } \\
\text { in 2days }\end{array}$ & & & & & & & & \\
\hline $\begin{array}{l}\text { No clean } \\
\text { postnatal }\end{array}$ & & & & & & & & \\
\hline $\begin{array}{l}\text { Clean } \\
\text { postnatal }\end{array}$ & $\begin{array}{l}0.32(0.13- \\
0.81)^{\star}\end{array}$ & $\begin{array}{l}0.41(0.17- \\
0.99)^{\star}\end{array}$ & $\begin{array}{l}0.28(0.07- \\
1.10)\end{array}$ & $\begin{array}{l}0.45(0.20- \\
1.04)\end{array}$ & $\begin{array}{l}0.36(0.15- \\
0.90)^{\star}\end{array}$ & $\begin{array}{l}0.18(0.06- \\
0.52)^{\star \star}\end{array}$ & $\begin{array}{l}0.38(0.09- \\
1.58)\end{array}$ & $\begin{array}{l}0.40(0.16- \\
1.01)\end{array}$ \\
\hline $\begin{array}{l}\text { Iron intake }>90 \\
\text { days }\end{array}$ & & & & & & & & \\
\hline No iron intake & & & & & & & & \\
\hline Iron intake & $\begin{array}{l}1.41(0.70- \\
2.86)\end{array}$ & $\begin{array}{l}1.29(0.64- \\
2.58)\end{array}$ & $\begin{array}{l}1.07(0.45- \\
2.56)\end{array}$ & $\begin{array}{l}1.21(0.60- \\
2.44)\end{array}$ & $\begin{array}{l}1.29(0.56- \\
2.99)\end{array}$ & $\begin{array}{l}1.58(0.78- \\
3.24)\end{array}$ & $\begin{array}{l}1.87(0.71- \\
4.94)\end{array}$ & $\begin{array}{l}1.50(0.73- \\
3.10)\end{array}$ \\
\hline IPTp & & & & & & & & \\
\hline No IPTp & & & & & & & & \\
\hline IPTp & $\begin{array}{l}1.63(0.77- \\
3.45)\end{array}$ & $\begin{array}{l}1.90(1.06- \\
3.69)\end{array}$ & $\begin{array}{l}1.73(0.78- \\
3.87)\end{array}$ & $\begin{array}{l}1.67(0.86- \\
3.26)\end{array}$ & $\begin{array}{l}1.17(0.61- \\
2.22)\end{array}$ & $\begin{array}{l}1.74(0.79- \\
3.82)\end{array}$ & $\begin{array}{l}0.84(0.36- \\
1.94)\end{array}$ & $\begin{array}{l}1.47(0.74- \\
2.94)\end{array}$ \\
\hline NHIS status & & & & & & & & \\
\hline Not covered & & & & & & & & \\
\hline Covered & $\begin{array}{l}0.46(0.25- \\
0.85)^{\star}\end{array}$ & $\begin{array}{l}0.59(0.33- \\
1.07)\end{array}$ & $\begin{array}{l}0.64(0.31- \\
1.33)\end{array}$ & $\begin{array}{l}0.60(0.33- \\
1.08)\end{array}$ & $\begin{array}{l}0.30(0.13- \\
0.69)^{\star}\end{array}$ & $\begin{array}{l}0.51(0.24- \\
1.11)\end{array}$ & $\begin{array}{l}0.63(0.28- \\
1.40)\end{array}$ & $\begin{array}{l}0.51(0.28- \\
0.95)^{\star}\end{array}$ \\
\hline
\end{tabular}

NB: P-value notation: ${ }^{*} p<0.05,{ }^{*} p<0.01,{ }^{* \star} p<0.001$. Statistical significance with $95 \%$ confidence interval, unadjusted odds ratios (OR) and adjusted odds ratios (aOR).

Table 3: Background factors and mortality among children under-five years old $(n=6,098)$ 


\begin{tabular}{|c|c|c|c|}
\hline Characteristics & Total n (\%) & Alive n (\%) & Died n (\%) \\
\hline \multicolumn{4}{|l|}{ Age(months) } \\
\hline$<1$ & $114(1.8)$ & $67(1.1)$ & $47(47.0)^{\star \star \star}$ \\
\hline 1 to 5 & $839(13.2)$ & $826(13.2)$ & $13(12.8)$ \\
\hline 6 to 11 & $896(14.9)$ & $881(14.9)$ & $15(16.0)$ \\
\hline 12 to 59 & $4,249(70.1)$ & $4,231(70.8)$ & $18(24.2)$ \\
\hline Female & $2,937(47.7)$ & $2,894(47.7)$ & $43(45.0)$ \\
\hline Birth size $(<2.5 \mathrm{~kg})$ & 771(11.7) & 755(11.7) & $16(14.3)$ \\
\hline \multicolumn{4}{|c|}{ Preceding birth interval } \\
\hline$<2$ years & $530(9.30)$ & $517(9.2)$ & $13(15.97)$ \\
\hline Birth order $(>=3)$ & $2,589(40.3)$ & $2,533(40.0)$ & $56(56.3)^{\star}$ \\
\hline Caesarean delivery & $572(11.1)$ & $563(11.1)$ & $9.0(12)$ \\
\hline Multiple birth & $153(2.5)$ & $144(2.4)$ & $9.0(10.1)^{\star \star \star}$ \\
\hline Had NHIS & $3,661(55.0)$ & $3,611(55.1)$ & $50(46.4)$ \\
\hline \multicolumn{4}{|l|}{ Region } \\
\hline Northern belt & $2,039(20.3)$ & $1,998(20.2)$ & $41(29.5)^{\star}$ \\
\hline Middle belt & $1,890(36.5)$ & $1,862(36.5)$ & $28(40.7)$ \\
\hline Southern belt & $2,169(43.2)$ & $2,145(43.4)$ & $24(29.8)$ \\
\hline \multicolumn{4}{|l|}{ Place of residence } \\
\hline Urban & $2,394(44.2)$ & $2,363(44,3)$ & $31(37.3)$ \\
\hline Rural & $3,704(55.8)$ & $3,642(55.7)$ & $62(62.7)$ \\
\hline \multicolumn{4}{|l|}{ Wealth quintile } \\
\hline Poorest & $1,896(22.2)$ & $1,857(22.0)$ & $39(33.2)$ \\
\hline Poorer & $1,315(20.8)$ & $1,294(20.7)$ & $21(22.0)$ \\
\hline Middle & $1,098(19.3)$ & $1,084(19.3)$ & $14(17.2)$ \\
\hline Richer & $1,009(20.0)$ & $998(20.0)$ & 11(17.4) \\
\hline Richest & $780(17.8)$ & $772(17.9)$ & $8(10.1)$ \\
\hline \multicolumn{4}{|c|}{ No. of children $<5$ years in household } \\
\hline $1-2$ & $5,326(88.1)$ & $5,245(88.1)$ & $81(87.8)$ \\
\hline 3-9 & $772(11.9)$ & $760(11.9)$ & $12(12.2)$ \\
\hline \multicolumn{4}{|l|}{ Household size } \\
\hline$<6$ & $3,354(58.5)$ & $3,312(58.7)$ & $42(45.6) *$ \\
\hline$>=6$ & $2,744(41.5)$ & $2,693(41.3)$ & $51(54.4)$ \\
\hline \multicolumn{4}{|c|}{ Mother's Employment status } \\
\hline Not employed & $1,059(17.4)$ & $1,041(17.3)$ & $18(21.0)$ \\
\hline Employed & $5,026(82.6)$ & $4,951(82.7)$ & $75(79.0)$ \\
\hline \multicolumn{4}{|l|}{ Mother's age } \\
\hline$<35$ & $4,207(69.5)$ & $4,151(69.5)$ & $56(65.7)$ \\
\hline
\end{tabular}

Page 20/26 


\begin{tabular}{|c|c|c|c|}
\hline 35 to 49 & $1,891(30.5)$ & $1,854(30.5)$ & $37(34.3)$ \\
\hline \multicolumn{4}{|l|}{ Maternal education } \\
\hline None & $2,119(28.2)$ & $2,077(28.0)$ & 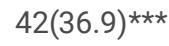 \\
\hline Primary & $1,305(21.1)$ & $1,278(20.9)$ & $27(37.0)$ \\
\hline Secondary or more & $2,674(50.8)$ & $2,650(51.1)$ & $24(26.1)$ \\
\hline \multicolumn{4}{|l|}{ Religion } \\
\hline Orthodox & $1,490(22.9)$ & $1,470(22.9)$ & $20(21.7)$ \\
\hline Pentecostal & $2,788(51.7)$ & 2,755(51.9) & $33(40.9)$ \\
\hline Islam & $1,235(17.3)$ & 1,208(17.2) & $27(22.0)$ \\
\hline Others & $585(8.16)$ & $572(8.01)$ & 13(15.4) \\
\hline \multicolumn{4}{|l|}{ Married status } \\
\hline Not married & $1,945(35.3)$ & 1,915(35.3) & $30(37.3)$ \\
\hline Married & $4,154(64.7)$ & $4,090(64.7)$ & $63(62.7)$ \\
\hline \multicolumn{4}{|l|}{ Polygamous home } \\
\hline No & $4,229(83.3)$ & $4,179(83.5)$ & $50(72.0)^{\star}$ \\
\hline Yes & $1,037(16.7)$ & 1,013(16.6) & $24(28.0)$ \\
\hline \multicolumn{4}{|l|}{ Ethnicity } \\
\hline Akan & $2,308(46.5)$ & $2,281(46.6)$ & $27(38.9)$ \\
\hline Mole-Dagbani & $1,618(18.4)$ & $1,589(18.3)$ & $29(20.6)$ \\
\hline Others(Ga/Dangbe/Eve) & $2,172(35.1)$ & $2,135(35.0)$ & $37(40.5)$ \\
\hline \multicolumn{4}{|l|}{ Maternal anaemia } \\
\hline Not anaemic & 2802(45.1) & $2656(42.8)$ & $146(2.25)$ \\
\hline Anaemic & 3092(54.9) & 2904(51.8) & $188(3.2)$ \\
\hline \multicolumn{4}{|c|}{ Maternal Body Mass Index (BMI) } \\
\hline Normal & $3197(69.8)$ & $3112(59.3)$ & $85(1.5)$ \\
\hline Abnormal & 1899(39.2) & 1855(38.3) & $44(0.94)$ \\
\hline \multicolumn{4}{|l|}{ Maternal height } \\
\hline$>145 \mathrm{~cm}$ & 4041(98.8) & 3978(97.3) & $63(1.5)$ \\
\hline$<=145 \mathrm{~cm}$ & $49(1.2)$ & $47(1.2)$ & $2(0.05)$ \\
\hline \multicolumn{4}{|c|}{ Infant given other milk with 3days after birth } \\
\hline No & $5935(98.0)$ & $5869(98.0)$ & $66(100)$ \\
\hline Yes & $105(2.0)$ & $0(0.0)$ & $105(2.0)$ \\
\hline Total & $6,098(100)$ & $6,005(98.5)$ & $93(1.46)$ \\
\hline
\end{tabular}

Note: $\mathrm{N}=$ total sample. $\mathrm{n}=$ number of observations. Sample size of birth interval was 6,084, child's weight was 6,079, NHIS coverage was 6,097, employment status was 6,085 while polygamy status 5,266 . Others were anaemia was, maternal height $(4,090)$, BMI $(3,497)$ and given other milk within three days after birth $(6,040) .{ }^{\star S}$ tatistical significance is at alpha of $5 \%$. 
Table 4: Coverage of interventions and mortality among children under-five years old $(n=6,098)$

\begin{tabular}{|c|c|c|c|c|}
\hline Characteristic & Total & Alive & Died & p-value \\
\hline Improved water source & 4,413(68.7) & $4,338(68.6)$ & $75(76.0)$ & 0.20 \\
\hline Water connected & $4,69(8.1)$ & $461(8.1)$ & $8(7.3)$ & 0.81 \\
\hline Improved sanitation & $560(10.3)$ & $552(10.4)$ & $8(6.9)$ & 0.25 \\
\hline Hygienic disposal of stool & $2,392(42.0)$ & $2,372(42.2)$ & $20(23.4)$ & 0.002 \\
\hline Antenatal care visit & $5,045(84.0)$ & $4,979(84.1)$ & $66(76.5)$ & 0.07 \\
\hline \multirow[t]{2}{*}{ Intermittent Preventive Treatment of Malaria in Pregnancy (IPT-p) } & $3,658(59.7)$ & & $53(59.5)$ & \\
\hline & & $3,605(59.7)$ & & 0.97 \\
\hline Iron(90day+) & $3,047(53.2)$ & $3,002(53.2)$ & $45(52.8)$ & 0.94 \\
\hline Tetanus toxoid vaccination & 4,515(76.3) & $4,451(76.3)$ & $64(70.2)$ & 0.22 \\
\hline Health facility delivery & $4,047(69.7)$ & $3,993(69.8)$ & $54(64.1)$ & 0.30 \\
\hline Skilled delivery & $4,109(70.7)$ & $4,054(70.8)$ & $55(66.0)$ & 0.38 \\
\hline Contraceptives use & $1,647(27.7)$ & $1,630(27.8)$ & $17(21.3)$ & 0.26 \\
\hline Clean postnatal care & $1,153(17.6)$ & $1,142(17.7)$ & 11(7.8) & 0.01 \\
\hline Early breastfeeding & $4,152(66.7)$ & $4,113(67.1)$ & $39(39.7)$ & $<0.001$ \\
\hline \multirow[t]{2}{*}{ Insecticide Treated Net/Indoor Residual Spraying (ITN/IRS) } & $4,984(79.4)$ & & $71(73.1)$ & \\
\hline & & $4,913(79.5)$ & & 0.19 \\
\hline Eight (8) interventions & $58(1.4)$ & $58(1.4)$ & $0(0.00)$ & NA \\
\hline Total & $6,098(100)$ & $6,005(98.5)$ & $93(1.46)$ & \\
\hline
\end{tabular}

$\mathrm{N}=$ total sample. $\mathrm{n}=$ number of observations. Eight interventions are: antenatal visit, IPT-p, iron (90day+), tetanus toxoid vaccine, skilled delivery, clean postnatal care, early initiation of breastfeeding and household ITN/IRS coverage. *Statistical significance at $95 \%$ confidence interval.

Table 5: Interventions with causal effect on under-five mortality

\begin{tabular}{|llll|}
\hline Intervention & Sample size & OR(95\%Cl) & aOR $(95 \% \mathrm{Cl})$ \\
\hline Early initiation of breastfeeding & 6,072 & $0.32(0.19-0.54)^{\star \star \star}$ & $0.39(0.22-0.71)^{\star \star \star}$ \\
\hline Clean postnatal care & 5,768 & $0.35(0.18-0.70)^{\star \star}$ & $0.36(0.15-0.90)^{\star}$ \\
\hline Intermittent preventive treatment of malarial in pregnancy & 5,965 & $1.14(0.44-2.98)$ & $1.74(0.79-3.82)$ \\
\hline Skilled delivery & 6,040 & $0.83(0.49-1.41)$ & $1.41(0.54-3.66)$ \\
\hline Tetanus toxoid vaccine & 5,980 & $0.82(0.47-1.40)$ & $0.86(0.41-1.79)$ \\
\hline Hygienic disposal of stool & 6,043 & $0.51(0.26-1.00)$ & $0.74(0.33-1.66)$ \\
\hline Iron intake & 6,045 & $1.37(0.72,2.61)$ & $1.07(0.48-2.56)$ \\
\hline Antenatal care & 5,951 & $2.77(1.27-6.05)^{\star}$ & $1.78(0.80-3.97)$ \\
\hline
\end{tabular}

NB: P-value notation: ${ }^{*} p<0.05,{ }^{* *} p<0.01,{ }^{* *} \mathrm{p}<0.001$. Statistical significance with $95 \%$ confidence interval, unadjusted odds ratios (OR) and adjusted odds ratios (aOR).

Table 6: Factors associated with under-five mortality among children 0-59 months $(\mathrm{N}=6098)$ 


\begin{tabular}{|c|c|c|}
\hline Characteristics & OR $(95 \% \mathrm{Cl})$ & $\mathrm{aOR}(95 \% \mathrm{Cl})$ \\
\hline \multicolumn{3}{|l|}{ Survey year } \\
\hline \multicolumn{3}{|l|}{2008} \\
\hline 2014 & $0.63(0.40,0.60)$ & $0.87(0.48-1.59)$ \\
\hline \multicolumn{3}{|l|}{ Age(months) } \\
\hline \multicolumn{3}{|l|}{$<1$} \\
\hline 1 to 5 & $0.02(0.01,0.05)^{\star \star \star}$ & $0.02(0.01-0.04)^{\star \star \star}$ \\
\hline 6 to 11 & $0.03(0.01,0.06)$ & $0.02(0.01-0.05)$ \\
\hline 12 and above & $0.01(0.004,0.02$ & $0.01(0.002-0.01)$ \\
\hline \multicolumn{3}{|l|}{ Gender } \\
\hline \multicolumn{3}{|l|}{ Male } \\
\hline Female & $0.90(0.57,1.41)$ & $0.91(0.50-1.64)$ \\
\hline \multicolumn{3}{|l|}{ Birth interval } \\
\hline \multicolumn{3}{|l|}{$>=2$ years } \\
\hline Less than 2 & $1.88(0.94,3.76)$ & $2.25(1.10-4.60)^{\star}$ \\
\hline \multicolumn{3}{|l|}{ Birth order } \\
\hline \multicolumn{3}{|l|}{ Below 3} \\
\hline$>=3$ & $1.95(1.21,3.14) *$ & $1.82(0.87-3.89)$ \\
\hline \multicolumn{3}{|l|}{ Birth weight } \\
\hline \multicolumn{3}{|l|}{ Normal } \\
\hline Small & $1.26(.67-2.37)$ & $0.83(0.32-2.18)$ \\
\hline \multicolumn{3}{|l|}{ Multiple birth } \\
\hline \multicolumn{3}{|l|}{ Singleton } \\
\hline Multiple birth & $4.99(2.20-11.33)^{\star \star \star}$ & $6.68(1.56-28.56)^{\star}$ \\
\hline \multicolumn{3}{|l|}{ Delivery type } \\
\hline \multicolumn{3}{|l|}{ Vaginal } \\
\hline Caesarean & $1.09(0.50-2.41)$ & $0.91(0.36-2.26)$ \\
\hline \multicolumn{3}{|l|}{ Region } \\
\hline \multicolumn{3}{|l|}{ Northern belt } \\
\hline Middle belt & $0.74(0.43-1.28)^{*}$ & $0.74(0.31-1.74)$ \\
\hline Southern belt & $0.46(0.26-0.83)$ & $0.45(0.16-1.25)$ \\
\hline \multicolumn{3}{|l|}{ Urban/rural } \\
\hline \multicolumn{3}{|l|}{ Urban } \\
\hline Rural & $1.34(0.82-2.18)$ & $0.83(0.34-2.03)$ \\
\hline \multicolumn{3}{|l|}{ Wealth quintile } \\
\hline \multicolumn{3}{|l|}{ Poorest } \\
\hline Poorer & $0.70(0.37-1.33)$ & $0.91(0.35-2.37)$ \\
\hline Middle & $0.59(0.29-1.19)$ & $1.06(0.33-3.37)$ \\
\hline Richer & $0.58(0.27-1.22)$ & $0.81(0.19-3.52)$ \\
\hline Richest & $0.37(0.15-0.94)$ & $1.11(0.22-5.71)$ \\
\hline
\end{tabular}

Page 23/26 


\begin{tabular}{|c|c|c|}
\hline \multicolumn{3}{|l|}{ Polygamous home } \\
\hline \multicolumn{3}{|l|}{ Not polygamous } \\
\hline Polygamous & $1.99(1.14-3.49) *$ & $2.16(1.05-4.44)^{*}$ \\
\hline \multicolumn{3}{|l|}{ Household size } \\
\hline \multicolumn{3}{|l|}{$<6$} \\
\hline$>=6$ & $1.69(1.05,2.72) *$ & $1.01(0.46-2.23)$ \\
\hline \multicolumn{3}{|c|}{ No. of CU5 in household } \\
\hline \multicolumn{3}{|l|}{$1-2$} \\
\hline 3 and above & $1.03(0.52-2.04)$ & $0.19(0.07-0.51)^{\star \star}$ \\
\hline \multicolumn{3}{|l|}{ Maternal age } \\
\hline \multicolumn{3}{|l|}{$<35$} \\
\hline$>=35$ & $1.19(0.73-1.93)$ & $0.83(0.40-1.74)$ \\
\hline \multicolumn{3}{|l|}{ Maternal education } \\
\hline \multicolumn{3}{|l|}{ None } \\
\hline Primary & $1.44(0.82-2.53)^{\star \star \star}$ & $1.23(0.51-2.95)$ \\
\hline Secondary or higher & $0.36(0.20-0.65)$ & $0.53(0.21-1.35)$ \\
\hline \multicolumn{3}{|l|}{ Married } \\
\hline \multicolumn{3}{|l|}{ Not Married } \\
\hline Married & $0.92(0.56-1.50)$ & $0.62(0.31-1.25)$ \\
\hline \multicolumn{3}{|l|}{ Religion } \\
\hline \multicolumn{3}{|l|}{ Orthodox } \\
\hline Pentecostal & $0.83(0.45,1.55)$ & $0.91(0.40-2.06)$ \\
\hline Islam & $1.35(0.67,2.72)$ & $1.34(0.52-3.45)$ \\
\hline Others & $2.02(0.90,4.55)$ & $1.31(0.43-3.96)$ \\
\hline \multicolumn{3}{|l|}{ Ethnicity } \\
\hline \multicolumn{3}{|l|}{ Akan } \\
\hline Mole-Dagbani & $1.35(0.74-2.45)$ & $0.62(0.19-2.05)$ \\
\hline Others & $1.39(0.80-2.40)$ & $1.18(0.52-2.64)$ \\
\hline \multicolumn{3}{|l|}{ Mother's employment } \\
\hline \multicolumn{3}{|l|}{ Not employed } \\
\hline Employed & $0.21(0.13-1.1)$ & $0.75(0.34-1.68)$ \\
\hline \multicolumn{3}{|l|}{ Contraceptives use } \\
\hline \multicolumn{3}{|l|}{ No use } \\
\hline Use & $0.71(0.38-1.30)$ & $1.36(0.61-3.01)$ \\
\hline \multicolumn{3}{|l|}{ Sanitation } \\
\hline \multicolumn{3}{|l|}{ Not improved } \\
\hline Improved & $0.64(0.29-1.38)$ & $0.95(0.36-2.47)$ \\
\hline \multicolumn{3}{|l|}{ Antenatal visits } \\
\hline \multicolumn{3}{|l|}{$<4$ plus visits } \\
\hline $4+$ visit & $0.61(0.36-1.04)$ & $0.82(0.40-1.68)$ \\
\hline
\end{tabular}

Page 24/26 


\begin{tabular}{|c|c|c|}
\hline \multicolumn{3}{|l|}{ Not received } \\
\hline Received & $0.73(0.44-1.21)$ & $0.82(0.39-1.71)$ \\
\hline \multicolumn{3}{|l|}{ Skilled delivery } \\
\hline \multicolumn{3}{|l|}{ Not skilled } \\
\hline Skilled & $0.80(0.49-1.32)$ & $1.60(0.65-3.91)$ \\
\hline \multicolumn{3}{|c|}{ Improved water source } \\
\hline \multicolumn{3}{|l|}{ Not improved } \\
\hline Improved & $1.45(0.82-2.55)$ & $1.46(0.68-3.13)$ \\
\hline \multicolumn{3}{|l|}{ Water connected } \\
\hline \multicolumn{3}{|l|}{ Not connected } \\
\hline Connected & $0.89(0.35-2.26)$ & $0.66(0.19-2.27)$ \\
\hline \multicolumn{3}{|c|}{ ITN/IRS protection } \\
\hline \multicolumn{3}{|l|}{ Not protected } \\
\hline Protected & $0.70(0.41-1.20)$ & $0.75(0.36-1.55)$ \\
\hline \multicolumn{3}{|c|}{ Hygienic disposal of stool } \\
\hline \multicolumn{3}{|l|}{ Not hygienic } \\
\hline Hygienic & $0.35(0.20-0.62)^{\star \star \star}$ & $0.58(0.32-1.07)$ \\
\hline \multicolumn{3}{|c|}{ Clean postnatal care in 2days } \\
\hline \multicolumn{3}{|c|}{ No clean postnatal } \\
\hline Clean postnatal & $0.36(0.18-0.71)^{\star \star}$ & $0.39(0.15-0.99) *$ \\
\hline \multicolumn{3}{|c|}{ Iron intake $>90$ days } \\
\hline \multicolumn{3}{|l|}{ No iron intake } \\
\hline Iron intake & $0.98(0.62-1.55)$ & $1.52(0.77-3.01)$ \\
\hline \multicolumn{3}{|c|}{ Early breastfeeding } \\
\hline \multicolumn{3}{|l|}{ Not early } \\
\hline Early & $1.20(0.33-2.76)$ & $0.39(0.21-0.73)^{\star \star \star}$ \\
\hline \multicolumn{3}{|l|}{ IPTp } \\
\hline \multicolumn{3}{|l|}{ No IPTp } \\
\hline IPTp & $0.99(0.62-1.58)$ & $1.44(0.74-2.83)$ \\
\hline \multicolumn{3}{|l|}{ NHIS status } \\
\hline \multicolumn{3}{|l|}{ Not covered } \\
\hline Covered & $0.70(0.44-1.13)^{*}$ & $0.54(0.31-0.96)^{*}$ \\
\hline
\end{tabular}

NB: P-value notation: ${ }^{*} \mathrm{p}<0.05,{ }^{* *} \mathrm{p}<0.01,{ }^{* \star *} \mathrm{p}<0.001$. Statistical significance with $95 \%$ confidence interval, unadjusted odds ratios (OR) and adjusted odds ratios (aOR)

\section{Figures}




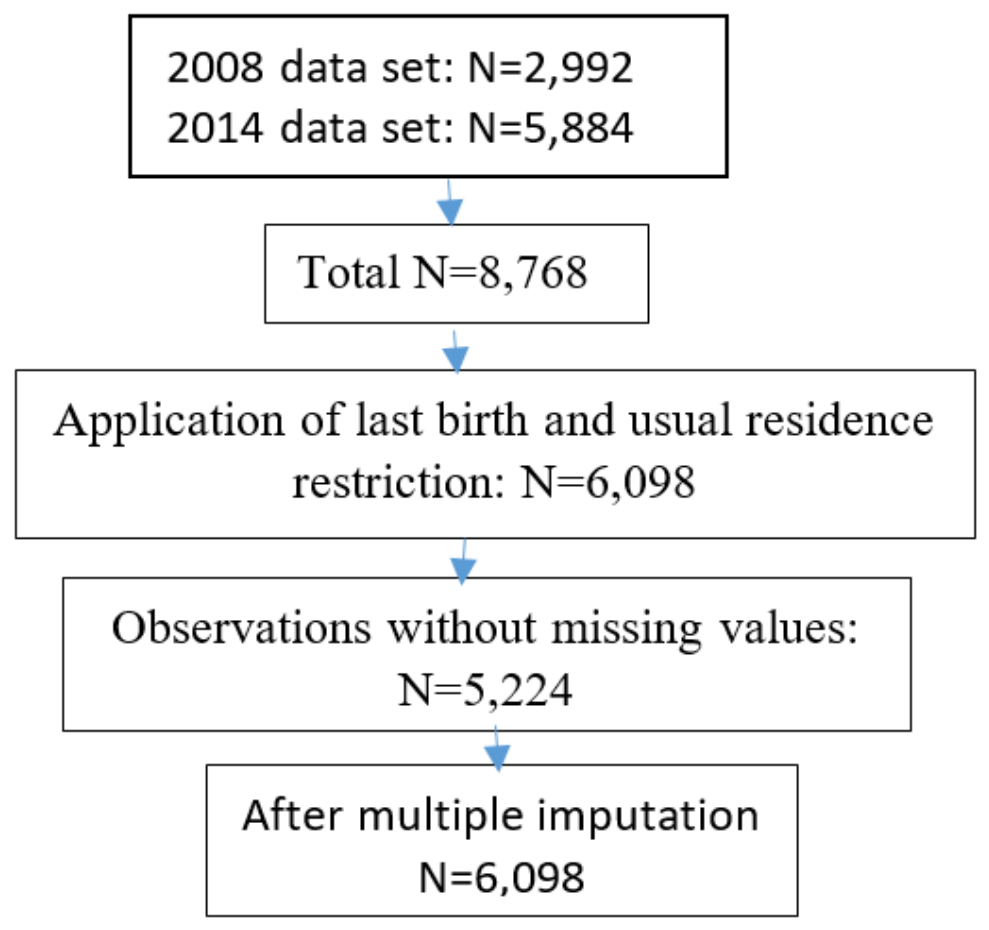

Figure 1

Flowchart of number of observations.

\section{Supplementary Files}

This is a list of supplementary files associated with this preprint. Click to download.

- Additionalfile1.docx 